\title{
Muhasebe Mesleğinin Geleceği Boyutunda Akademik Yayınların Bibliyometrik Analizi
}

\author{
Bibliometric Analysis of Academic Publications in the Future of the Accounting \\ Profession
}

\section{Öz}

Amaç: Çalışmada "teknoloji tabanlı muhasebenin geleceği”" boyutunda rehber metodolojiyi takip etmek amaciyla 2000-2020 yılları arasında bibliyometrik analiz yapılmıștır.

Tasarım/Yöntem: Muhasebe mesleği dijital geleceğe doğru yol alırken "dijital muhasebe ve eğitim, bilgi teknolojileri ve muhasebe, muhasebe denetimi ve teknoloji" kapsamında yayınlanan akademik çalışmalar "Web of Science", "Scopus", "TR Dizin" ve "Google School" veri tabanlarından elde edilmiștir. Elde edilen veriler bibliyometrik analiz yazılımı Vosviewer (1.6.16) haritalama tekniğiyle görselleştirilmiştir.

Bulgular: Web of Science veri tabanında yapılan araştırmada 34 ülkenin 87 yayınına ulașılmıștır. Yayınların ülkelere göre dağılımının bibliyometrik analizinde en çok yayın yapan $(\% 17)$ ve yayınlarına en fazla atıf alan (\% 29) ülke ABD'dir. En çok yayını olan üniversiteler, 29 yayın ve $\% 6$ pay ile Finlandiya merkezli Aalto ve Turku Üniversiteleridir. ABD'de Arkansas Üniversitesi 26 yayınla \% 4,9'luk paya sahip. Scopus veri tabanında 32 ülkeden 154 yayın elde edilmiştir. ABD 20 yayın ve \% 13 pay ile ilk sırada yer almaktadır. Yayınlarına en çok atıf alan ülke 751 atıf ve $\% 60$ pay ile ABD'dir. En çok yayını olan üniversiteler, 482 atıf ve\% 38 'lik pay ile ABD'de Georgia Eyalet Üniversitesi'dir. Veri tabanlarında Türkiye kaynaklı bir yayına rastlanmamıștır. TR Dizini ve Google School veri tabanında, Türkiye'de mesleğinin dijital geleceği konusu kapsamında yapılan araştırmada 50 dergide 132 makalenin yer aldığ 8 kongrenin katkı sağladığı tespit edilmiştir. Muhasebe mesleğinin teknolojik gelişimine en fazla katkı sağlayan dergilerin başında \%14 pay ile "Muhasebe ve Finansman" dergisi gelmektedir.

Sınırlılıklar: TR Dizini ve Google School veri tabanında, tekniğin kullanılamaması çalışmanın sınırlığıdır.

Özgünlük/Değer: Konu kapsamında, veri tabanlarından elde edilen verilere dayanarak Vosviewer haritalama tekniğiyle yapılan bibliyometrik analiz yazında ilk çalışmadır. Çalışma ile araştırmacılar için sistematik bir bilgi haritası sağlamak amaçlanmıștır.

Anahtar Kelimeler: Dijital Muhasebe Mesleği, Bibliyometrik Analiz, VOSviewer Haritalama Tekniği

\begin{abstract}
Purpose: In the study, a bibliometric analysis was conducted between 2000-2020 to follow the guiding methodology in the dimension of "the future of technology-based accounting".

Design/Methodology: As the accounting profession moves towards the digital future, academic studies published within the scope of "digital accounting and education, information technologies and accounting, accounting auditing and technology", "Web of Science", "Scopus", "TR Index" and "Google School". It has been obtained from databases. The data obtained were visualized with the bibliometric analysis software Vosviewer (1.6.16) mapping technique.

Findings: 87 publications from 34 countries were reached in the research conducted in the Web of Science database. In the bibliometric analysis of the distribution of the publications by country, the country with the highest number of publications $(17 \%)$ and the most citations (29\%) in the USA. The universities with the most publications are Aalto and Turku Universities based in Finland with 29 publications and $6 \%$ share. In the USA, Arkansas University has a share of $4.9 \%$ with 26 publications. In the Scopus database, 154 publications from 32 countries were obtained. The USA ranks first with 20 publications and $13 \%$ share. The country with the most citations to his publications is the USA with 751 citations and a share of $60 \%$. The universities with the most publications are Georgia State University in the USA with 482 citations and a share of $38 \%$. No publications originating from Turkey were found in the databases. In the research conducted within the scope of the digital future of the profession in Turkey in the TR Directory and Google School database, it was determined that 8 congresses with 132 articles in 50 journals contributed. "Accounting and Finance" magazine comes first with a $14 \%$ share among the journals contributing the most to the technological development of the accounting profession.

Limitations: The fact that the technique cannot be used in the TR Directory and Google School database is the limitation of the study. Originality/Value: It is the first study in the literature of bibliometric analysis conducted with the Vosviewer mapping technique based on data obtained from databases within the scope of the subject. The study aims to provide a systematic information map for researchers.

Keywords: Digital Accounting Profession, Bibliographic Analysis, Vosviewer Mapping Technique
\end{abstract}

\footnotetext{
${ }^{1}$ Doç. Dr., Bursa Uludağ Üniversitesi, Mustafakemalpaşa Meslek Yüksekokulu, Muhasebe ve Vergi Uygulamaları Bölümü, gissever@uludag.edu.tr, ORCID: 0000-0002-5942-1278
} 


\section{GİRIŞ}

M.Ö 3000'li yıllara kadar uzanan bir geçmişe sahip olan muhasebe, Luca Pacioli döneminde muhasebe kuramlarının yerleşmesiyle şekillenmiştir. XIX. yüzyılın ikinci yarısında, Avrupa ve Amerika'da başlayan endüstri 2.0 sanayileşme devrimi yıllarında, Sir William Rowan Hamilton tarafından çift girișli defter tutma sistemi geliștirilmiştir (Güvemli, 2012). Başlangıçta, ekonomik faaliyetleri manuel olarak kayıt altına alma, özetleme ve raporlama gibi muhasebe uygulamaları, 20. yüzyılın son çeyreğinde teknolojide yaşanan gelişim ve değişim ile elektronik ortama taşınmıştır. Teknoloji tabanlı paket programların sisteme girmesi ve ülke ekonomilerine özel getirilen yasal düzenlemelerle muhasebe bilimi, değişim gücüne sahip olmaya başlamıştır.

Tarih boyunca ülkelerin gelişmişlik düzeyleri devrimsel buluşlara yaptıkları ev sahipliğiyle ve devrimsel gelişmelere adapte olma gücüyle ilintili olmuştur. Sanayi devrimleri ile gelen süreç ülkelerin küreselleşme boyutunu hızlandırmış sermayenin serbest dolaşımını güçlendirmiştir. 21. yüzyılın ilk dönemi muhasebe ve finansal raporlama standartlarının ve denetim standartlarının küreselleşmesine tanıklık etmiştir. 21. yüzyılda insan zekasının bir ürünü olan dijital bilgi çağı adım, adım derinlik kazanmaya başlamıştır. Ancak, bir tuşla mali verilerin hazırlanması karar vericiler için etkili pozisyonlar yaratmış olmakla birlikte "Uluslararası Muhasebe ve Finansal Raporlama Standartları"nın (UFRS/UMS) getirdiği büyük verilerin kullanımı muhasebecilerin önünde en büyük handikap haline gelmiştir. Muhasebe süreçlerinin teknolojiye evrilmesiyle, terabaytlarca veriyi meslek mensuplarının analiz edip karar vericilerin kullanımına hazır hale getirmesi önem kazanmıştır.

Yeni konum ve donanım yapısıyla çağa adını veren endüstri 4.0 teknoloji tabanlı gelişmelere çığır açmıştır. Küresel dünyada teknolojik gelişmeler her mesleğin yapı taşlarında devinim yaratıı̆ı gibi ekonomi dünyasının odağında yer alan muhasebe mesleğini ve uygulamalarını da etkisi altına almıştır. Genç yüzyılın en büyük kazanımı, araştırmacıların, akademisyenlerin ve uygulayıcıların birikimlerinin coğrafi konumdan bağımsız paylaşılabilir olmasıdır.

Teknolojik gelişim, disiplinler arası devinim başlatmıştır. Muhasebe biliminin de bu devinimde yerini alması kaçınılmaz görünmektedir. (Nixon, 2012). Günümüzde ülkeler endüstri 4.0'ın önemini kavrayarak sürece adapte olmaya çalışmaktadır. Endüstri 4.0 ile bilgi teknolojileri muhasebenin konumunu yeniden şekillendirmektedir. Yerli ve yabancı literatürde yer alan çalışmalar, sürekli gelişen teknolojilerin mesleği hangi boyuta taşıyabileceğine odaklanmaktadır. Muhasebenin temel fonksiyonlarının ve muhasebeciye olan gereksinimin değişmeyeceği ancak akıllı sistemlerin rutin işlemleri üstlenmesinden dolayı işgücüne ihtiyacın azalacağı savunulmaktadır (Ford, 2009; Frey \& Osborne, 2013; Ghani \& Muhammad 2019).

Schwab ve Samans (2016) ABD'de 700 meslek dalının teknolojiye adaptasyon düzeyini araştırmışlar, muhasebe ve denetim mesleklerinin \%94 oranında akıllı sistemlere uyarlanabileceği yönünde çıkarım yapmışlardır. Nitekim "Dünya Ekonomik Forumu"nun tahminleri, teknolojiye adaptasyonun 5 milyondan fazla net iş kaybına yol açacağı yönündedir. Dünyada önemli bir muhasebe kuruluşu olan "Yeminli Mali Müşavirler Derneği (the Association of Chartered Certified Accountants$A C C A)$ " 150 ülkeden 19.000 öğrenciyi kapsayan çalışmasında, Y kuşağının teknolojik donanıma sahip olduğunu ve muhasebenin analiz ve karar verme ruhunu ön plana çıkarabileceğini tespit etmiştir (World Economic Forum, 2016). Veri analiz kuruluşu Statista'nın verilerine göre, 2010 yılında dünyada üretilen yıllık veri miktarı 2 zettabyte $^{1}$ iken, 2018 yılında 33 zettabyte ulaşmış, 2025 yılına kadar ise, 175 zettabyte'a ulaşabileceği açıklanmıştır. Çok daha çarpıcı bir açıklama ise, son iki yılda üretilen veri miktarının, insanlığın başlangıcından bu güne kadar toplanmış veri miktarından daha fazla olduğudur (Statista, 2019). Dünya Ekonomik Forumu'nun raporuna göre, 2020'nin başında dijital evrenin 44 zettabayt veriden oluştuğu, 2025'e kadar, dünya çapında her 24 saatte bir yaklaşık 463 exabayt verinin de oluşabileceği tahmin edilmektedir (World Economic Forum, 2019).

Muhasebe verilerinin üstsel bir hızla artması ve fonksiyonlarının dijitalleşmesi, mesleğin uygulayıcılarının proaktif yaklaşım ihtiyacını öne çıkarmıştır. Muhasebe mesleğinin çağın gerçekleriyle örtüşmesi için meslek mensuplarının etkili pozisyonlar alması, değiş̧ikliklere liderlik

\footnotetext{
${ }^{1} 2$ zettabyte $=(2,000,000,000,000 \mathrm{~GB})$
} 
etmesi noktasında literatürde geniş bir fikir birliği bulunmaktadır (Burritt \& Christ, 2016; Kruskopf, vd., 2019).

Çalışmada, küresel boyutta gelişimi hızla devam eden bilgi teknolojilerinin dünya ülkelerinde ve Türkiye'de muhasebe bilimine yansımalarının izini sürmek ve gelecekteki çalışmaların seyrine katk1 sağlamak amacıyla, 2000-2020 yıllarında literatürde yerini alan makale ve bildiri çalışmaları bibliyometrik analiz yöntemiyle incelenmiştir. Bibliyometrik analiz için, ilk olarak "Web of Science", "Scopus" da indekslenen dergiler kapsamında tarama yapılmış ve bir bibliyometrik yazılımı olan VOSviewer üzerinden görsel haritalama tekniğiyle resmedilmiştir. Böylece dijiyal muhasebe literatürü, holistik yaklaşımla değerlendirilmiştir. Konunun Türkiye'de ki gelişimini görmek amacıyla da "TR Dizin" ve "Google school”"dan elde edilen literatür verileri kantitatif olarak analiz edilmiştir.

Literatürde yer alan çalışmalar; bilişim sistemlerinin; mesleki eğitim, mesleki uygulamalar, denetim işlevi, etik anlayış üzerindeki etkisini değerlendirmeyi konu edinmekte, geleceğe yönelik mesleki firsat ve olası risk öngörüleri bağlamında mesleğe katkı sağlamaktadır. Çalışmada, pradigmal yaklaşımla taranan akademik çalışmalar bağlamında genel bir profil ortaya konmaktadır.

\section{ARAŞTIRMA METODOLOJISİ}

Bu bölümde araştırmanın; amacı, yöntemi, bulgular ve değerlendirmelere yer verilmiştir.

\subsection{Araștırmanın Amacı}

21. yüzyılda dünyada teknoloji tabanlı gelişmelerden etkilenmeden aynı kalan bir meslek olduğunu söylemek neredeyse imkansızdır. Literatürde endüstri 4.0 devrimi olarak ifade edilen; siber fiziksel sistemler, yapay zeka, bulut bilişim gibi teknolojilerinin çı̆̆ gibi büyümesiyle, muhasebenin de yeniden kurgulanması kaçınılmaz olmuştur. Muhasebenin ve muhasebeden elde edilen verilerin dijital mecralarda vizyoner fikirlere evrilmesi, tüm dünyada akademisyenlerin araştırmalarını, geleceğin büyüsünün heyecanı içinde paradigmal yaklaşımla teknoloji odaklı çalışmalara yönlendirmektedir. Çalışmada, muhasebe mesleğini dijital geleceğe doğru taşıyacak rehber metodolojiyi takip etmek ve araştırmalara 1şık tutmak amacıyla bibliyometrik analiz yapılmıştır.

\subsection{Araștırmanın Yöntemi}

Çalışmada tüm dünya ülkelerini birbirine bağlayan teknolojik gerçeklikte, dijital muhasebe mesleğine yönelik bilimsel yayınların nicelik ve verimliliğini değerlendirmek, bilim insanlarının performanslarının yayılım etkinliğiyle ilgili bulgular sunmak, ülke ve kurum ölçeğinde yayın gücünü görebilmek amacıyla bibliyometrik bilimsel haritalama tekniği kullanılmıştır. Bibliyometri tekniği her bir bilim dalının yayın indeksinin haritasını çizerken; yayınların ülkeler arasındaki boyutunu, atıfların yoğunluğunu ve konunun yıllara yaygın serüvenindeki dağılımını gösteren bir bilimsel analizdir.

Veri tabanlarından sağlanan verilerle analiz yapma esasına dayanan bibliyometri analizi, yayın performans analizi ve bilimsel alanın dinamiklerini belirlemeye yönelik haritalama tekniğidir (Zupic \& C̆ater, 2015). Bibliyometri tekniği, uzun dönemli bir analiz sunarak bilimsel alanın geleceğe yönelik düşünsel ve uygulama yönünün ön plana çıkmasına yardımcı olur (Martinez vd., 2015). Akademik çalışmaların, tanımlayıcı istatistiksel verilerinin elde edilmesinin yanında çalışmaların atıf verisiyle, geleceği etkileme gücünü görmek açısından da önemli bilgi sağlar (Zhang vd., 2016). Akademisyen ve araştırmacıların performans göstergeleri olan bilimsel yayınlar aynı zamanda ülkelerin yayın gücünün bir göstergesi niteliğindedir. $\mathrm{Bu}$ bağlamda bibliyometrik analizler ile bilimsel literatürün evrim eğilimini keşfetmek mümkündür (Khalil \& Crawford, 2015).

\section{BULGULAR}

Çalışmada ilk olarak, Web of Science ve Scopus veri tabanında, 2000-2020 tarihleri arasında "Information Technologies and Accounting"," Accounting Audit and Technology", "Digital Accounting Education" başlığıyla, arama kayıtları elde edilmiştir. Web of Science'da SSCI (Social Science Citation Index), Emerging Sources'da endekslenen dergiler kapsamında tarama yapılmıştır. Veri kaynağı olarak Web of Science ve Scopus'un kullanılmasının nedeni, bibliyometrik araştırmalarda kullanılan ortak veri kaynakları olup online ortamlardaki en önemli veri tabanlarından olmasidir (Cobo vd., 2015). 
İkinci adımda çalışmaların analiz için "VOSviewer (version 1.6.16)" bilimsel haritalama tekniği kullanılmış ve bulgular yorumlanmıştır. VOSviewer, bilimsel literatürün görselleştirilmesinde kullanılan; CiteSpace, Bibexcel, CopalRed, IN-SPIRE, CRExplorer, Network Workbench Tool, Science of Science Tool, VantagePoint ve SciMAt gibi en yaygin haritalama tekniklerinden biridir (Pradhan, 2016).

Çalışmanın üçüncü adımında TR Dizin ve Google School'da araştırmanın konusunu oluşturan yerli literatür sonuçları elde edilmiş ve bulgular değerlendirilmiştir.

\subsection{Muhasebe Mesleğinin Geleceğine Yönelik Web of Science Veri Tabanında Yayınlanan Çalıșmalar}

Teknolojik gelişmeler odağında muhasebenin geleceğine ilişkin Web of Science veri tabanında 2000-2020 yıllarında 34 ülkenin 87 yayınına ulaşılmıştır. Yayınlar tek tek incelenmiş ve çalışma konusunu tam karşılayan yayınlar veri kümesine dahil edilmiştir.

\subsubsection{Web of Science veri tabanında yayınlanan yayınların yıllara göre dağılımı}

Çalışmada, konu kapsamında 2000 ve 2001 yıllarında bir yayına (\%1), 2003 yılında üç yayına (\%3) ulaşılmıştır. 2002, 2004, 2005 ve 2006 yıllarında ise bir yayına erişilmemiştir. Şekil 1'de izlenebildiği gibi 2007 yılından itibaren artış gösteren yayın yüzdesi 2018 yılında 10 yayın ile \% 11 'dir.

Şekil 1: 2000-2020 Yılları arasında Web of Science Veri Tabanında Yayınlanan Yayınların Yüzde Dağılımı ve Büyüme Eğilimi

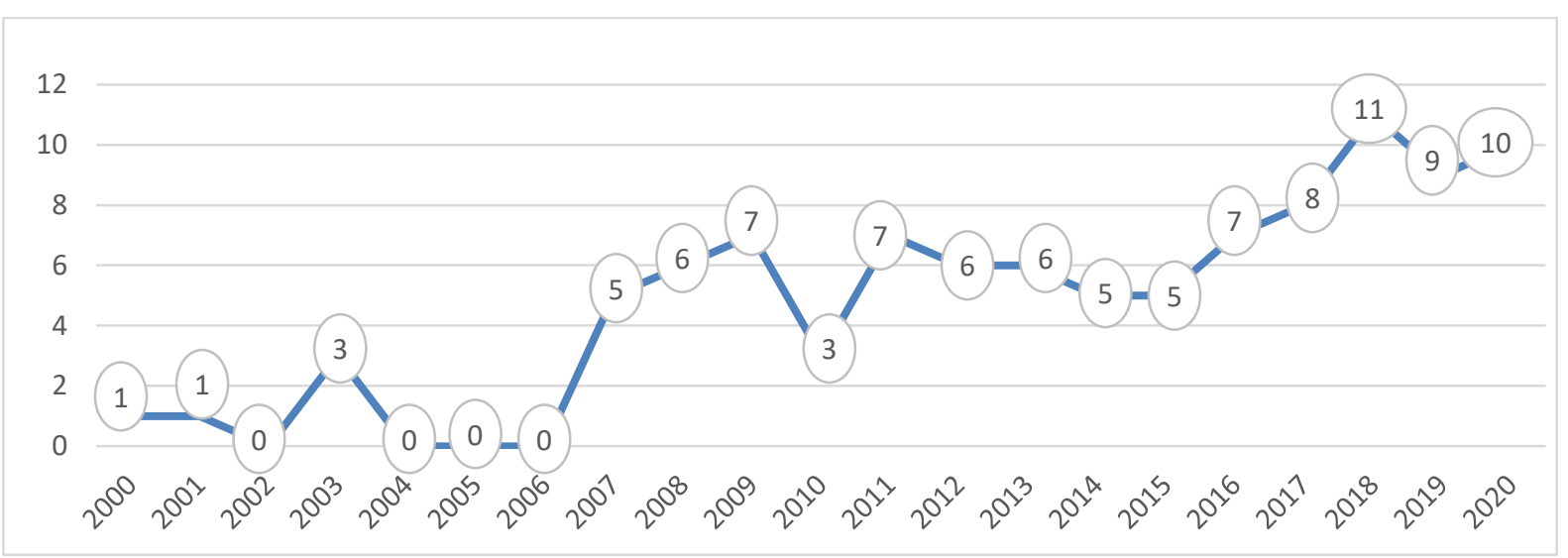

\subsubsection{Web of Science veri tabanında yayınlanan yayınların ülkelere göre dağılımı}

Tablo 1'de de görüldüğü gibi, teknolojik gelişmeler odağında muhasebe literatürüne en fazla katkı sağlayan ülke 15 yayın (\%17) ile Amerika Birleşik Devleri (ABD) olmuştur. ABD'yi Romanya $(\% 8)$, Endonezya (\%8), Çin (\%7) takip etmektedir. 17 ülke tek bir yayın ile \%1'lik bir düzeyde katk1 sağlarken Türkiye menşeli bir yayına rastlanılmamıştır.

Tablo 1: 2000-2020 Yılları arasında Yayınlanan Yayınların Ülkelere Göre Dağılımı

\begin{tabular}{lcclcc}
\hline Ülke & Yayın & Yüzde & Ülke & Yayın & Yüzde \\
\hline ABD & 15 & 17 & Kolombiya & 1 & 1 \\
\hline Romanya & 7 & 8 & Hirvatistan & 1 & 1 \\
\hline Endonezya & 7 & 8 & Çek Cumhuriyeti & 1 & 1 \\
\hline Çin & 6 & 7 & Danimarka & 1 & 1 \\
\hline Avustralya & 5 & 6 & Fransa & 1 & 1 \\
\hline İniltere & 5 & 6 & Almanya & 1 & 1 \\
\hline Kanada & 4 & 5 & Japonya & 1 & 1 \\
\hline İtalya & 3 & 3 & Litvanya & 1 & 1 \\
\hline Brezilya & 2 & 2 & Lüksemburg & 1 \\
\hline Yunanistan & 2 & 2 & Hollanda & 1 & 1 \\
\hline Misır & 2 & 2 & Yeni Zelanda & 1 & 1 \\
\hline Finlandiya & 2 & 2 & Portekiz & 1 & 1 \\
\hline İskoçya & 2 & 2 & Güney Afrika & & 1 \\
\hline
\end{tabular}


Tablo 1 (Devamı): 2000-2020 Yılları arasında Yayınlanan Yayınların Ülkelere Göre Dağılımı

\begin{tabular}{lcclcc}
\hline Ülke & Yayın & Yüzde & Ülke & Yayın & Yüzde \\
\hline İspanya & 2 & 2 & Güney Kore & 1 & 1 \\
\hline Tayvan & 2 & 2 & Arap emirlikleri & 1 & 1 \\
\hline Ukrayna & 2 & 2 & Venezuela & 1 & 1 \\
\hline Galler & 2 & 2 & İran & & 1 \\
\hline Toplam & $\mathbf{8 7}$ & & & $\mathbf{1 0 0}$ \\
\hline
\end{tabular}

Şekil 2‘de bilimsel yayınların, yayınlandıkları ülkelere göre dağılımlarının bibliyometrik ă̆ haritası verilmiştir. VOSviewer programıla yapılan analiz sonucunda elde edilen ağ haritası, konu kapsamındaki çalışmaların yayınlandığı ülkeler arasındaki ilişki gücünü göstermektedir. Bilimsel haritalama analiz tekniğiyle ağ haritası oluşturulurken bir ülkeye ait minimum yayın sayısı "1" olacak şekilde eşik değer belirlenmiştir. Eşik değeri karşılayan 34 ülkenin her birinin diğer ülkelerle olan bibliyografik eşleştirme bağlantılarının gücü hesaplanmış ve bağlantı gücü en yüksek olan ülkeler seçilerek harita oluşturulmuştur. Şekil 1'de görünen dairelerin büyüklüğü konu üzerinde en çok yayın yapan ülkeleri göstermektedir. Diğer bir ifadeyle dairelerin büyüklüğü konuyla ilgili çok yayının ve yazarın olduğunu ifade etmektedir (Eck \& Waltman, 2020). Buna göre, ABD en çok yayının ve yazarın olduğu ülkedir. ABD yayınları diğer ülkelerin yayınlarını etkileyen merkez ülke konumunda görünmektedir. Ülkeleri temsil eden dairelerin birbirine yakın olması yayınların benzerliğinin göstergesi olarak yorumlanmaktadır.

Şekil 2: 2000-2020 Yılları arasında Web of Science Veri Tabanında Yayınlanan Yayınların Ülkelere Göre Dağılımlarının Bibliyometrik Ağ Analizi

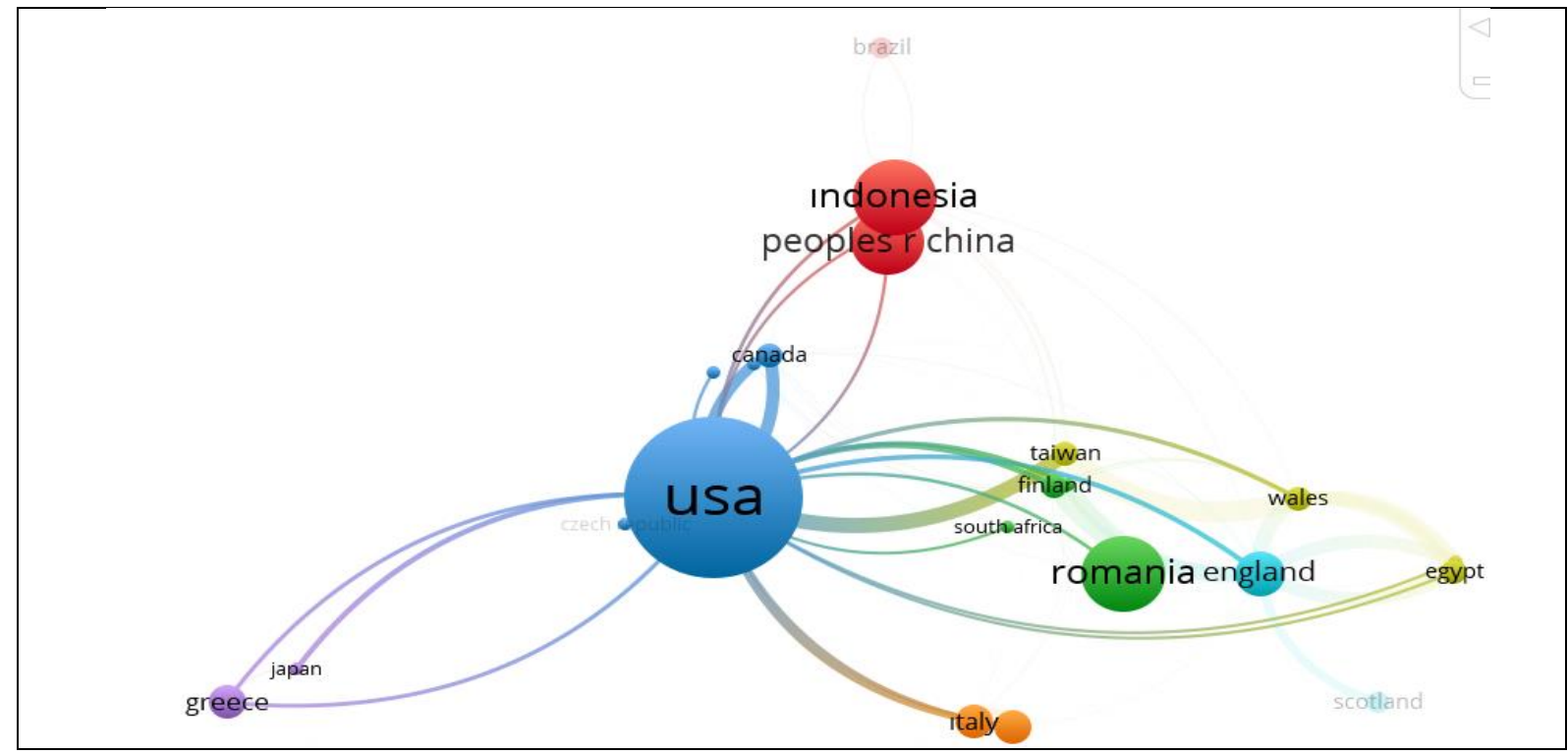

Ülkelerin dijital muhasebe konusundaki yayınlarına ilişkin yoğunluk haritası Şekil 3'de verilmiştir. Farklı renklerdeki kümeler ülkeleri ve yoğunluklarını göstermektedir. Kırmızı renk yoğunluğundaki ABD'nin, çalışma konusunda en güçlü bağlantılara sahip ve en çok dokümanı olan ülke olarak ilk sıralarda yer aldığ 1 görselleştirilmiştir. Benzer şekilde Endonezya, Çin ve Brezilya çok yakın kümelerde yer aldığı görülmektedir. Yine Romanya ve Litvanya, Güney Afrika, Tayvan ve Finlandiya'nın etkileşimleri dikkat çekmektedir. 
Şekil 3: 2000-2020 Yı1ları arasında Web of Science Veri Tabanında Yayınlanan Yayınların Ülkelere Göre Dağılımlarının Yoğunluk Haritası

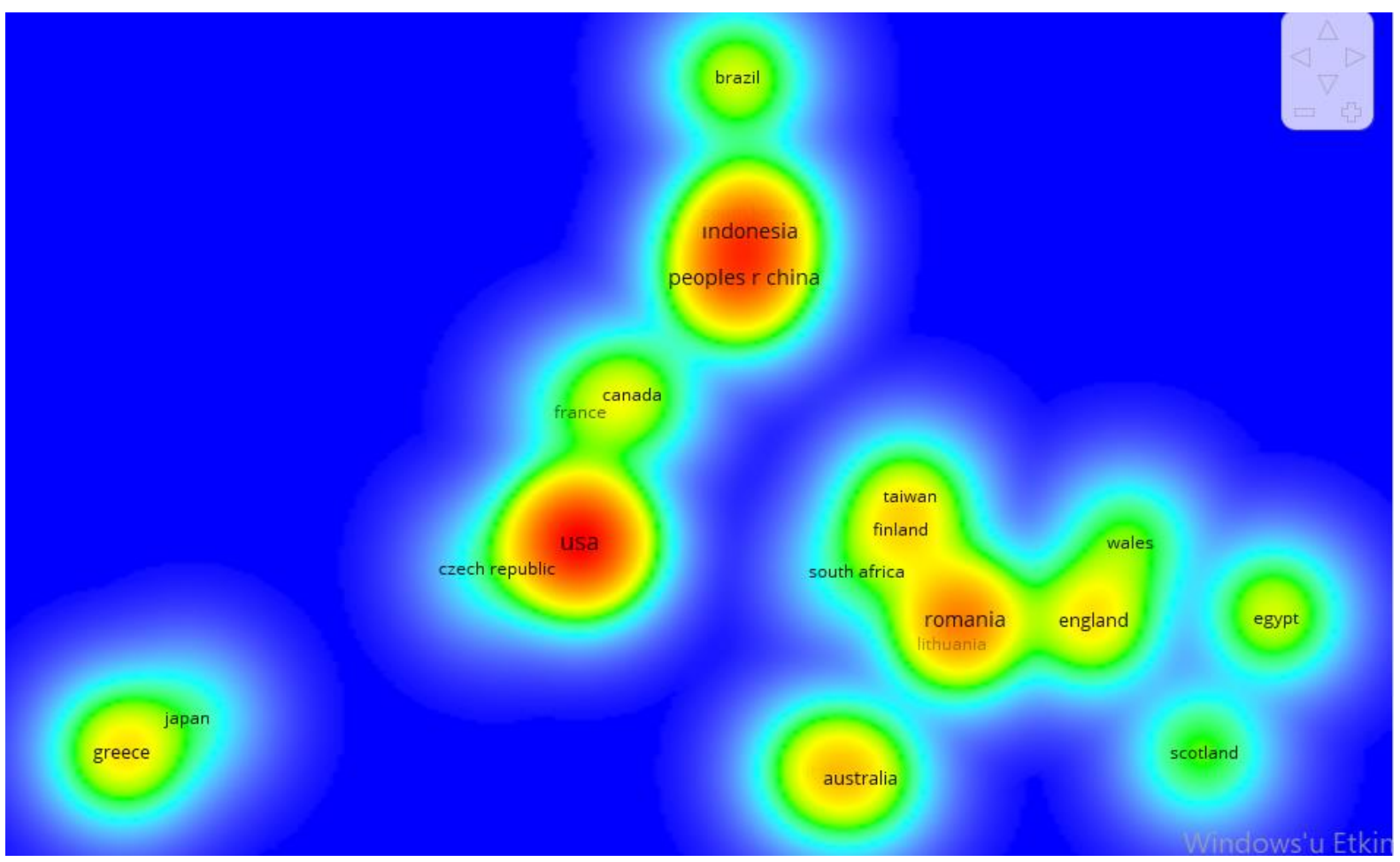

\subsubsection{Web of Science veri tabanında yayınlanan yayınlarda ülkelerin aldıkları atıf (citation) verilerinin dağılımı}

Atıf analizi, bibliyometrinin önemli alanıdır (Kurutkan \& Orhan, 2018). Atıf sayısı bir yayının kalitesinin ve bağlı olduğu ülkenin alanla ilgili bilimsel ve teknolojik etkinliğinin göstergesidir. (Kıdak vd., 2017). Tablo 2'de 34 ülkenin çalışma konusunda ulaşılan 87 yayınına toplam 524 atıf yapılmıştır.

Tablo 2: 2000-2020 Yılları arasında Yayınlanan Yayınlarda Ülkelerin Aldıkları Atıf Verileri ve Yüzde Dağılımı

\begin{tabular}{|c|c|c|c|c|c|}
\hline Ülke & Atıflar & Yüzde (\%) & Ülke & Atıflar & Yüzde (\%) \\
\hline $\mathrm{ABD}$ & 155 & 29 & İran & 8 & 2 \\
\hline Finlandiya & 49 & 10 & Misir & 8 & 2 \\
\hline İngiltere & 34 & 6 & Arap Emirlikleri & 7 & 1 \\
\hline Tayvan & 27 & 5 & Çin & 6 & 1 \\
\hline Avustralya & 23 & 4 & Endonezya & 6 & 1 \\
\hline Kanada & 23 & 4 & Hollanda & 6 & 1 \\
\hline Yeni Zelanda & 21 & 4 & Romanya & 5 & 1 \\
\hline Danimarka & 20 & 4 & Venezuela & 5 & 1 \\
\hline İspanya & 20 & 4 & Brezilya & 0 & 0 \\
\hline İtalya & 18 & 3 & Hirvatistan & 0 & 0 \\
\hline Yunanistan & 17 & 3 & Çek Cumhuriyeti & 0 & 0 \\
\hline Lüksemburg & 15 & 3 & Fransa & 0 & 0 \\
\hline Güney Kore & 15 & 3 & Almanya & 0 & 0 \\
\hline Galler & 10 & 2 & Japonya & 0 & 0 \\
\hline Kolombiya & 9 & 2 & Portekiz & 0 & 0 \\
\hline Litvanya & 9 & 2 & Güney Afrika & 0 & 0 \\
\hline İskoçya & 8 & 2 & Ukrayna & 0 & 0 \\
\hline Toplam & & & & 524 & 100 \\
\hline
\end{tabular}


Şekil 4: 2000-2020 Yılları arasında Web of Science Veri Tabanında Yayınlanan Yayınların Ülkeler Arasındaki Atıf Haritası

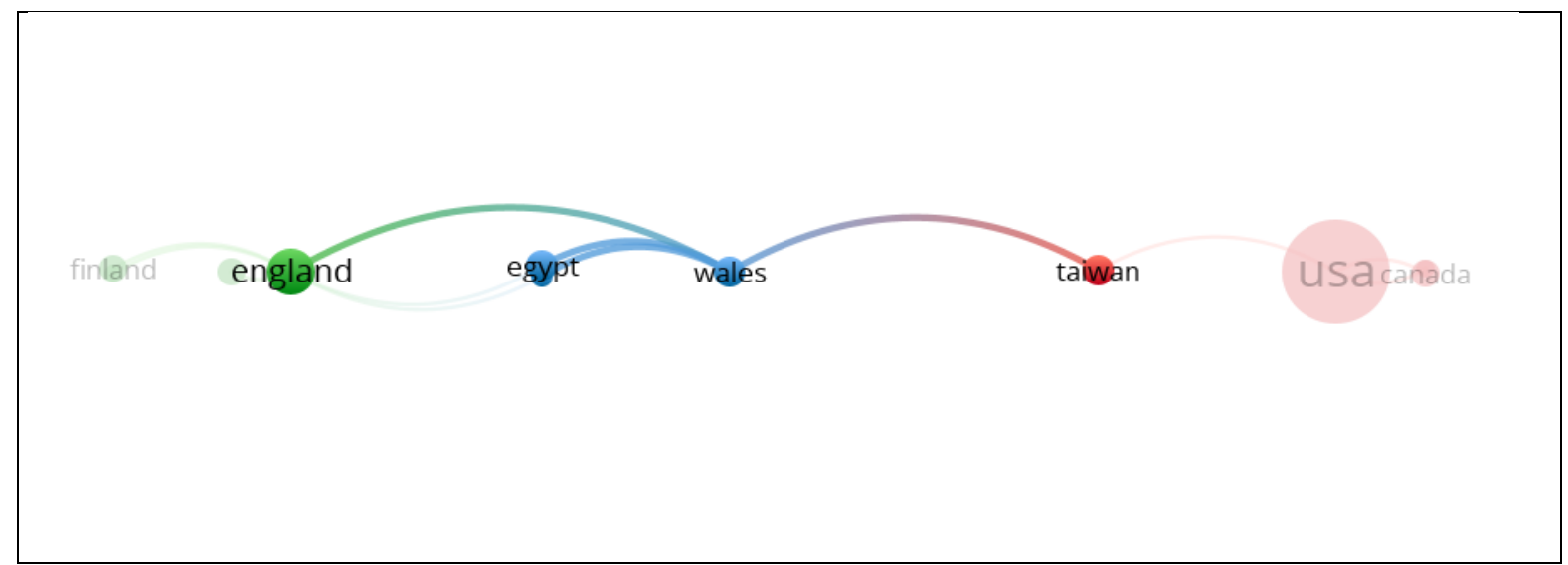

Ülkelerin bibliyografik eşleştirme (Bibliographic Coupling) verilerine dayalı haritalama görseli Şekil 4'de yer almaktadır. Bibliyografik eşleştirme iki farklı kaynağın aynı kaynağa atıfta bulunması olarak ifade edilmekte ve atıf analizlerinde kullanılmaktadır (Milfont, 2013). ABD, Tablo 2'de en fazla atıf alan (\%29) ülke olarak Şekil 4'de de en büyük yuvarlak daire olarak haritalanmıştır. Ülkelerin birbirleriyle atıf ilişkisinde ABD ile Kanada arasında çok fazla atıf beslemesi olduğu dikkat çekmektedir. Atıf ilişkisinin olduğu ülkeler aynı renkle boyandığı Şekil 4'de, İngiltere İskoçya ve Finlandiya arasında daha fazla atıf yapılmış olduğu görülmektedir. Yine Galler ile öncelikle Mısır, Tayvan ve İngiltere arasında güçlü bir atıf varlığı göze çarpmaktadır. verilmiştir.

Ülkelerin birbirlerinin yayınlarına yaptıkları atıfların yoğunluk haritası da Şekil 5 'de

Şekil 5: 2000-2020 Yilları arasında Web of Science Veri Tabanında Yayınlanan Yayınların Ülkeler Arasındaki Yoğunluk Haritası

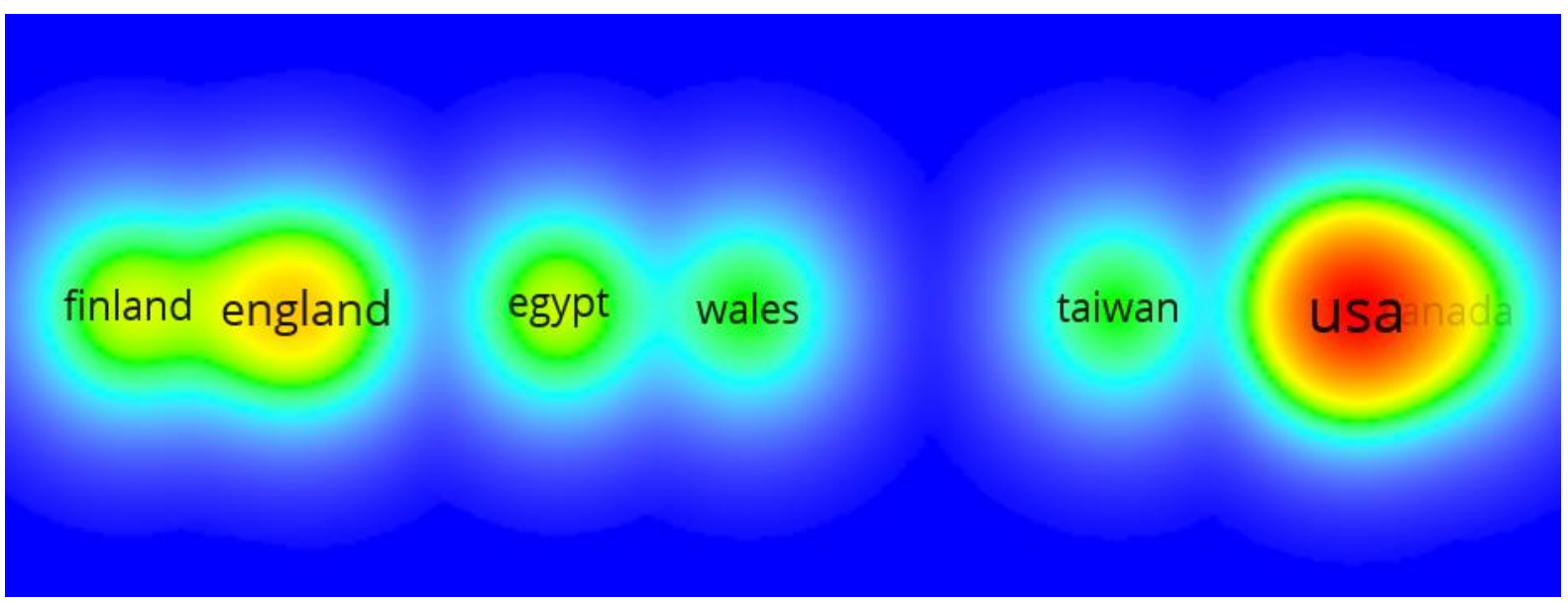

Amerika Birleşik Devletlerinin en fazla Kanada'dan atıf aldığı daha net olarak görülmektedir. Yoğunluk haritası incelendiğinde İngiltere'de yayınlanan makalelere en fazla Finlandiya'dan atıf yapıldığı, Finlandiya'nın da İngiltere'den atıf aldığı anlaşılmaktadır.

\subsubsection{Atıf alan yazarların (cited authours) haritalanması}

Atıf alan yazarlara ait görsel yoğunluk haritası Şekil 6'da gösterilmektedir. Yoğunluk haritası oluşturulurken her bir yazar için atıf sayısı eşik değeri "10" olarak seçilmiş̧ir. Daire büyüklüklerinin yazarlara ait yayın sayısını gösterdiği dikkate alındığında en fazla atıf alan yazarların Kaplan, Jorgenson, Deloitte, Banker, O’leary olduğu izlenmektedir. 
Şekil 6: Atıf Alan Yazarların Haritalaması

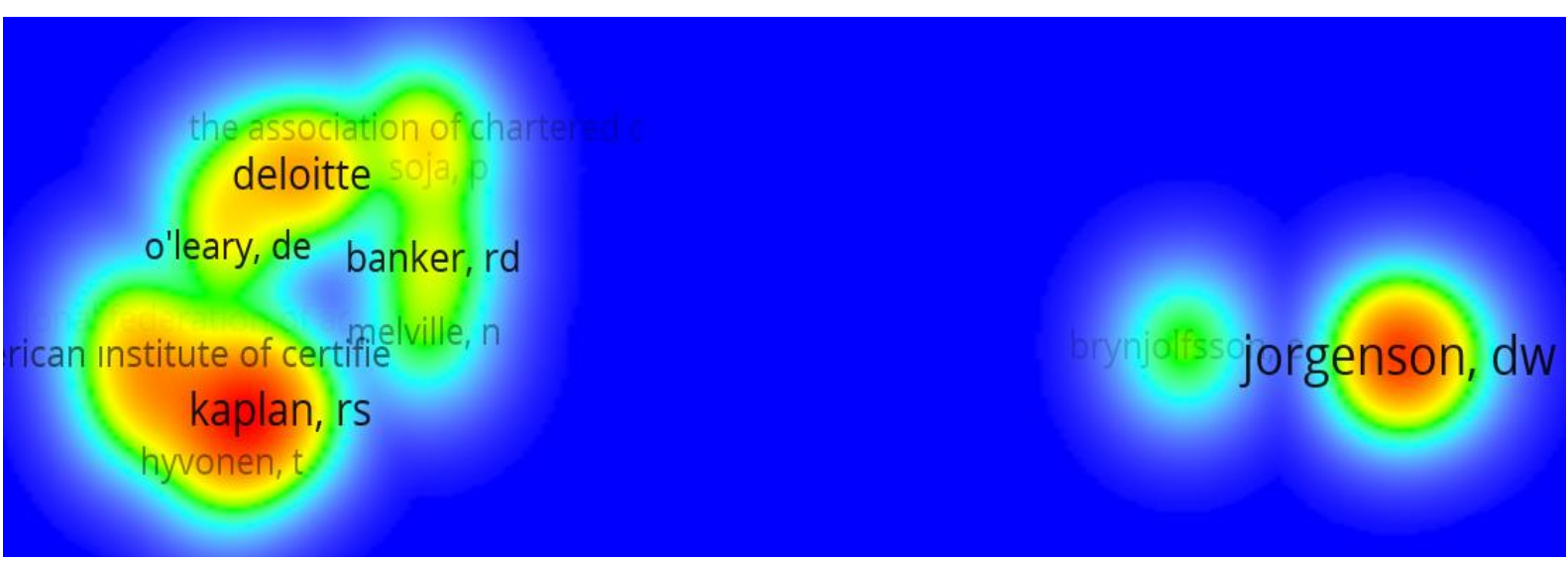

Dijital muhasebenin geleceğine yönelik en fazla katkı sağlayan yazarları ve aldıkları atıfları belirlemeye ilişkin yapılan analizden elde edilen sonuçlar Șekil 7'de sunulmaktadır. En fazla atıf alan yazarları belirlemeye yönelik analizde Jorgenson D.W. \%6 oranında atıfla ilk sıraya yerleşmiştir. Kaplan R.S. \%3, Deloitte \%2,6 oranında atıf yüzdesine sahiptir.

Şekil 7: Literatüre En Fazla Katkı Sağlayan Yazarlar ve Aldıkları Atıflar

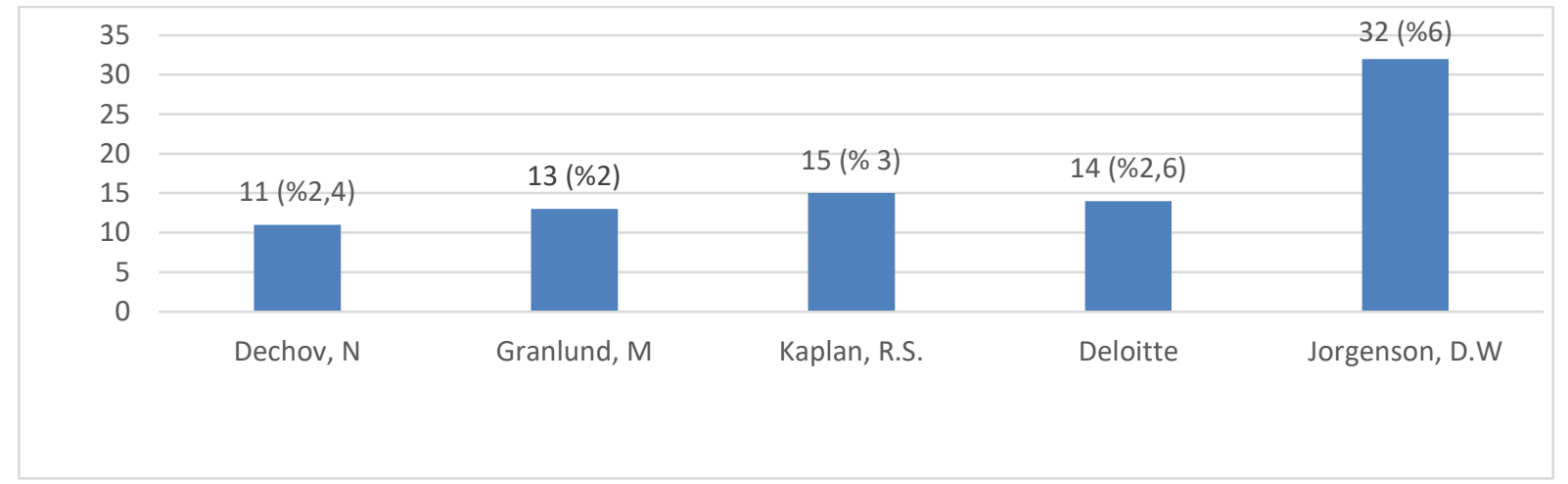

\subsubsection{Web of Science veri tabanında yayınlanan yayınlarda atıf alan üniversiteler ve bağlı oldukları ülkeler}

Web of Science veri tabanında yapılan çalışmada, 2000-2020 yılları arasında 34 ülkenin çalışma konusunda ulaşılan 87 yayınına toplam 524 atıf yapılmıştır. Bu atıfların \%29'u (155 atıf) ABD' de yayınlanan çalışmalara aittir. Tablo 3'de ABD'de yayınlarına en fazla atıf alan üniversitelerin Arkansas Üniversitesi ve Cent Florida Üniversitesi \%4,9 (26 atıf), Michigan State Üniversitesi ve Delaware Üniversitesi, \%4,7 (25 atıf) olduğu görülmektedir. Finlandiya üniversitelerinden Aalto Üniversitesi ve Turku Üniversitesi \%6 (29 atıf) ile en fazla atıf alan üniversitelerdir.

Tablo 3: 2000-2020 Yılları arasında Yayınlanan Yayınlarda Atıf Alan Üniversiteler ve Bağlı Oldukları Ülkeler

\begin{tabular}{lcc}
\hline Yayın Yapan & Atıf & Yüzde (\%) \\
\hline Aalto Üniversitesi-Finlandiya & 29 & 6 \\
\hline Turku Üniversitesi-Finlandiya & 29 & 6 \\
\hline Natl Taiwan Üniversitesi-Tayvan & 27 & 5,1 \\
\hline Arkansas Üniversitesi-ABD & 26 & 4,9 \\
\hline Cent Florida Üniversitesi-ABD & 26 & 4,9 \\
\hline Michigan State Üniversitesi-ABD & 25 & 4,7 \\
\hline Delaware Üniversitesi-ABD & 25 & 4,7 \\
\hline Missouri Üniversitesi-Columbia & 25 & 4,7 \\
\hline Diğer Üniversiteler & 312 & 59 \\
\hline Toplam & $\mathbf{5 2 4}$ & $\mathbf{1 0 0}$ \\
\hline
\end{tabular}




\subsection{Muhasebe Mesleğinin Geleceğine Yönelik Scopus Veri Tabanında Yayınlanan Çalışmalar}

Scopus veri tabanında, muhasebe mesleğinin geleceğine yönelik yapılan araştırmada, 32 ülkenin 154 yayınına ulaşılmıştır. Yayınlar tek tek incelenmiş ve çalışma konusunu tam karşılayan yayınlar veri kümesine dahil edilmiştir.

\subsubsection{Scopus veri tabanında yayınlanan yayınların yıllara göre yüzde dağılımı}

Özellikle son yıllarda konu kapsamında çalışma yüzdesinin arttı̆̆ gözlemlenmektedir (Şekil 8). 2000- 2013 yılları arasında $\% 3-\% 4$ genelinde çalışmaya rastlanırken 2014 y1lı itibariyle yükselme trendi izlenmektedir. Toplam yayınların \%8'i 2019 yılında, \%10'u ise 2020 yılında yapılmıştır.

Şekil 8: 2000-2020 Yılları arasında Scopus Veri Tabanında Yayınlanan Yayınların Yüzde Dağılımı ve Büyüme Eğilimi

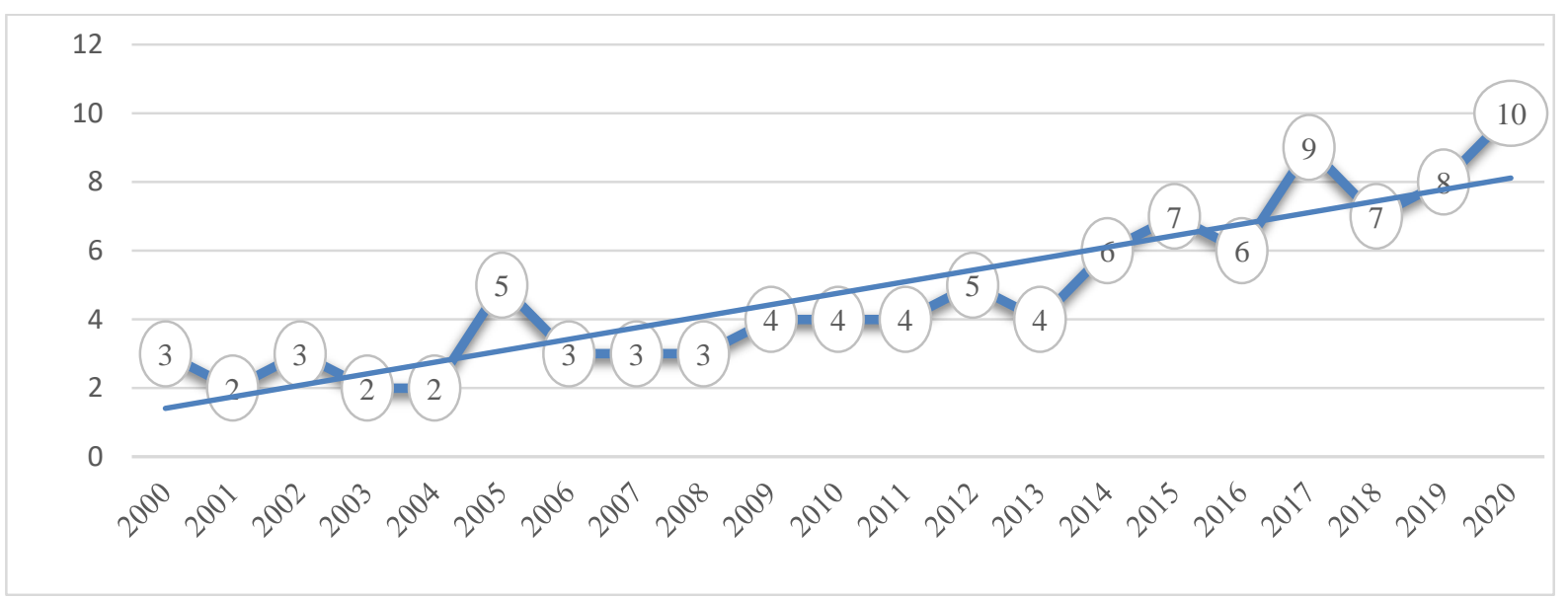

\subsubsection{Scopus veri tabanında yayınlanan yayınların ülkelere göre dağılımı}

Teknolojik gelişmeler odağında muhasebe literatürüne en fazla katkı sağlayan ülke 20 yayın ve \%13 oran ile Amerika Birleşik Devleri olmuştur (Tablo 3). ABD’yi 14 yayınla (\%9) Birleşik Krallık, 13 yayınla (\%8) Endonezya, 12 yayınla (\%8) Avustralya ve Malezya takip etmektedir. 14 ülke tek bir yayın ile \%1'lik bir düzeyde katkı sağlarken konuyla ilgili Türkiye menşeli bir yayına rastlanılmamıştır.

Tablo 4: 2000-2020 Yı1ları arasında Yayınlanan Yayınların Ülkelere Göre Dağılımı

\begin{tabular}{lcclcc}
\hline Ülke & Yayın & Yüzde & Ülke & Yayın & Yüzde \\
\hline ABD & 20 & 13 & Singapur & 2 & 1 \\
\hline Birleşik Krallı & 14 & 9 & Hirvatistan & 1 & 1 \\
\hline Endonezya & 13 & 8 & Finlandiya & 1 & 1 \\
\hline Avustralya & 12 & 8 & Tayland & 1 & 1 \\
\hline Malezya & 12 & 8 & Litvanya & 1 & 1 \\
\hline Kanada & 11 & 7 & Meksika & 1 & 1 \\
\hline Yeni Zelanda & 10 & 6 & Lüksemburg & 1 & 1 \\
\hline HongKong & 10 & 6 & Katar & 1 & 1 \\
\hline Çin & 8 & 5 & Brezilya & 1 & 1 \\
\hline Misır & 8 & Hindistan & 1 & 1 \\
\hline İran & 6 & 5 & Suudi Arabistan & 1 & 1 \\
\hline Tayvan & 3 & 4 & Güney Kore & 1 & 1 \\
\hline Ukrayna & 3 & 2 & Sudan & 1 & 1 \\
\hline İspanya & 2 & 2 & Yunanistan & 1 & 1 \\
\hline Ürdün & 2 & 1 & Birleşik Arap Emirlikleri & $\mathbf{1 5 4}$ \\
\hline Rusya & 2 & 1 & Portekiz & 1 \\
\hline Toplam & & 1 & 100 & 1 \\
\hline
\end{tabular}

Konu kapsamında ülkelerin bilimsel yayınlarının bibliyometrik ă̆ haritası Şekil 9' da verilmiştir. A $\breve{g}$ haritası oluşturulurken bir ülkeye ait minimum yayın sayısı "1" ve bir ülkenin aldığı minimum atıf sayısı "0" olacak şekilde eşik değerler belirlenmiştir. Eşik değeri karşılayan 32 ülkenin her birinin diğer ülkelerle olan bibliyografik eşleştirme bağlantılarının gücü hesaplanmış ve bağlantı 
gücü en yüksek olan ülkeler seçilerek harita oluşturulmuştur. Şekil 9'da dairelerin büyüklüğü, konu kapsamında yayın azlığını ve çokluğunu gösterirken aynı renge sahip daireler ülkeler arasında ortak çalışmaların varlığını temsil etmektedir. Buna göre en büyük daireyi temsil eden $\mathrm{ABD}$, en çok yayının ve yazarın olduğu ülke konumundadır. A $\breve{g}$ haritasındaki karmaşık yapı renklendirmeyle açıklanmaktadır. Aynı renkli ağlar ve dairelerin yakınlığı, ülkeler arasında yayınların içeriğinin benzerliğini göstermektedir (Perianes vd., 2016). ABD ile Hong Kong, Güney Kore, Hindistan arasında, Birleşik Krallık ile Mısır, Çin, Katar ve Tayvan arasında benzer şekilde Endonezya ile Malezya, Finlandiya, İspanya arasında, etki düzeyi daha fazladır. Konuyla ilgili çalışmalarının etki düzeyi az olan ülkeler ağ haritasında seçilememektedir.

Şekil 9: 2000-2020 Yılları arasında Scopus Veri Tabanında Yayınlanan Yayınların Ülkelere Göre Dağılımlarının Bibliyometrik A $\breve{g}$ Analizi

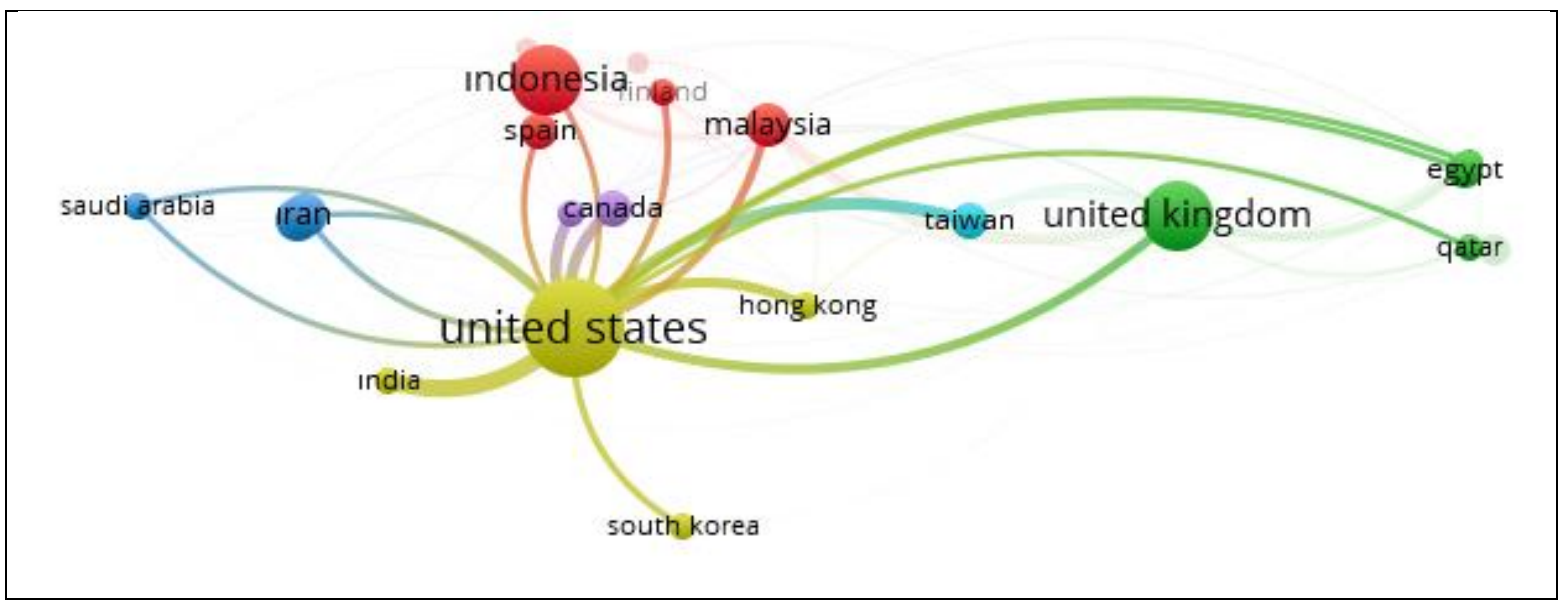

Şekil 10: 2000-2020 Yıılları arasında Scopus Veri Tabanında Yayınlanan Yayınların Ülkelere Göre Dağılımlarının Yoğunluk Haritası

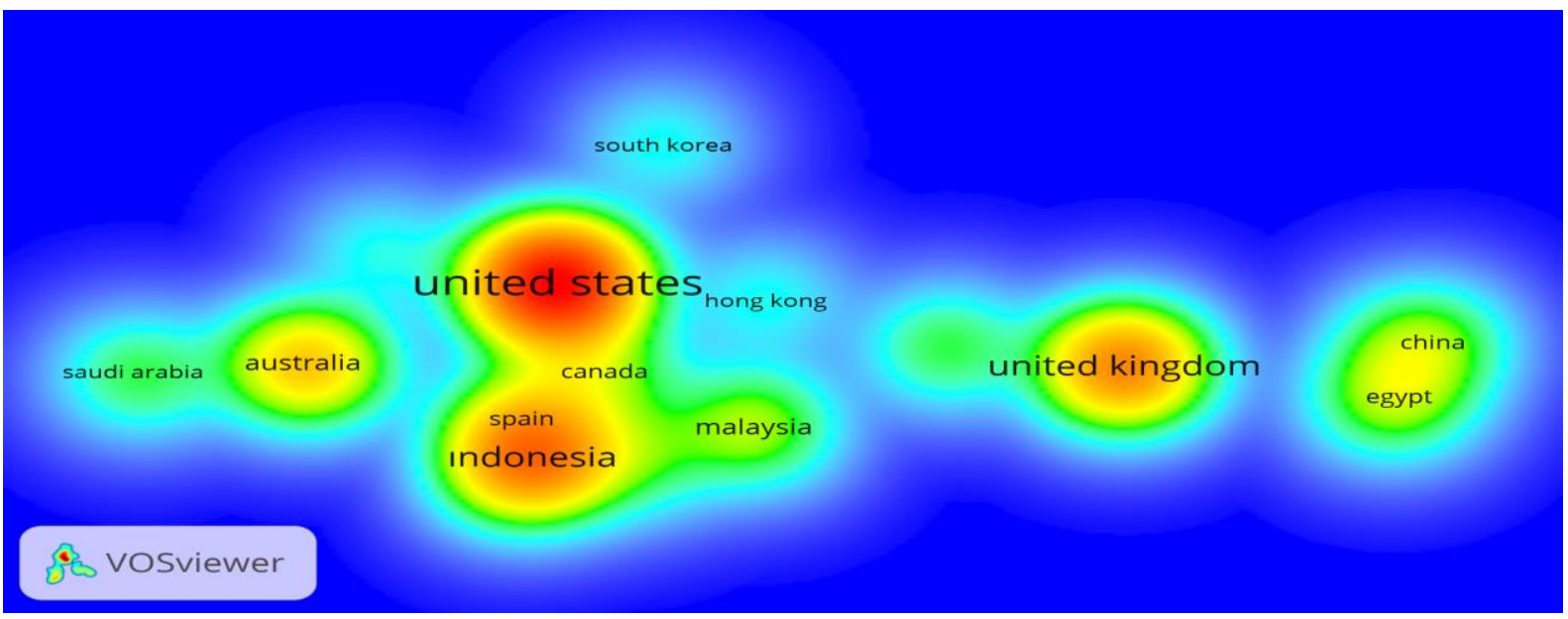

Ülkeler arası yayın etkileşiminin yoğunluk haritası Şekil 10'da gösterilmiştir. Kırmızı renk yoğunluğu, konuya katkısı en fazla olan ve diğer ülkeleri en fazla etkileyen ülkeleri göstermektedir. $\mathrm{Bu}$ durumda; ABD, Birleşik Krallık ve Endonezya, yayınları en çok tercih edilen ülkelerdir. Yeşil renk yoğunluğu içindeki ülkeler özellikle bu ülkelerin yayınlarından etkilenmektedir.

\subsubsection{Scopus veri tabanında yayınlanan yayınlarda ülkelerin aldıkları atıf (citation) verilerinin dağılımı}

Bibliyografik eşleştirmeye (Bibliographic Coupling) dayalı ülkelerin aldıkları atıf sayısı ve yüzde dağılımının, VOSviewer programından elde edilen verileri Tablo 5'de yer almaktadır. 32 ülkenin toplam 154 yayınına 1.256 atıf yapılmıştır. En çok atıf alan ülke 751 (\% 60) atıf ile ABD'dir. Birleşik Krallık ile Endonezya'nın yayın sayısı (14 ve 13) çok yakın olmakla beraber Endonezya'nın 
çok daha fazla atıf aldığı (84 atıf, \%7) dikkat çekmektedir. Tablo 5'de yayınları hiç atıf almayan ülkelerde verilmiştir.

Tablo 5: 2000-2020 Yılları arasında Yayınlanan Yayınlarda Ülkelerin Aldıkları Atıf (Citation) Verileri ve Yüzde Dağılımı

\begin{tabular}{lcclcc}
\hline Ülke & Atıflar & Yüzde & Ülke & Atıflar & Yüzde \\
\hline ABD & 751 & 60 & Kanada & 17 & 1,3 \\
\hline Endonezya & 84 & 7 & Güney Kore & 16 & 1,3 \\
\hline Finlandiya & 74 & 6 & Yeni Zelanda & 15 & 1,2 \\
\hline $\begin{array}{l}\text { Birleşik } \\
\text { Krallık }\end{array}$ & 37 & 3 & Yunanistan & 13 & 1 \\
\hline Hong Kong & 35 & 3 & Lüksemburg & 13 & 1 \\
\hline Çin & 35 & 3 & Katar & 8 & 0,7 \\
\hline Avustralya & 30 & 2,2 & Misır & 7 & 0,5 \\
\hline Tayvan & 29 & 2 & Birleşik Arap Emirlikleri & 6 & 0,4 \\
\hline Singapur & 21 & 1,6 & Malezya & 5 & 0,3 \\
\hline Hindistan & 21 & 1,6 & Tayland & 1 & 0,08 \\
\hline İspanya & 20 & 1,5 & Meksika & 1 & 0,08 \\
\hline Hirvatistan & 17 & 1,3 & İran - Ürdün - Rusya-Ukrayna-Brezilya- Litvanya-Suudi & 0 & 0 \\
\hline Toplam & & & Arabistan-Sudan-Portekiz & $\mathbf{1 . 2 5 6}$ & $\mathbf{1 0 0}$ \\
\hline
\end{tabular}

Şekil 11: 2000-2020 Yılları arasında Scopus Veri Tabanında Yayınlanan Yayınların Ülkeler Arasındaki Atıf Haritası

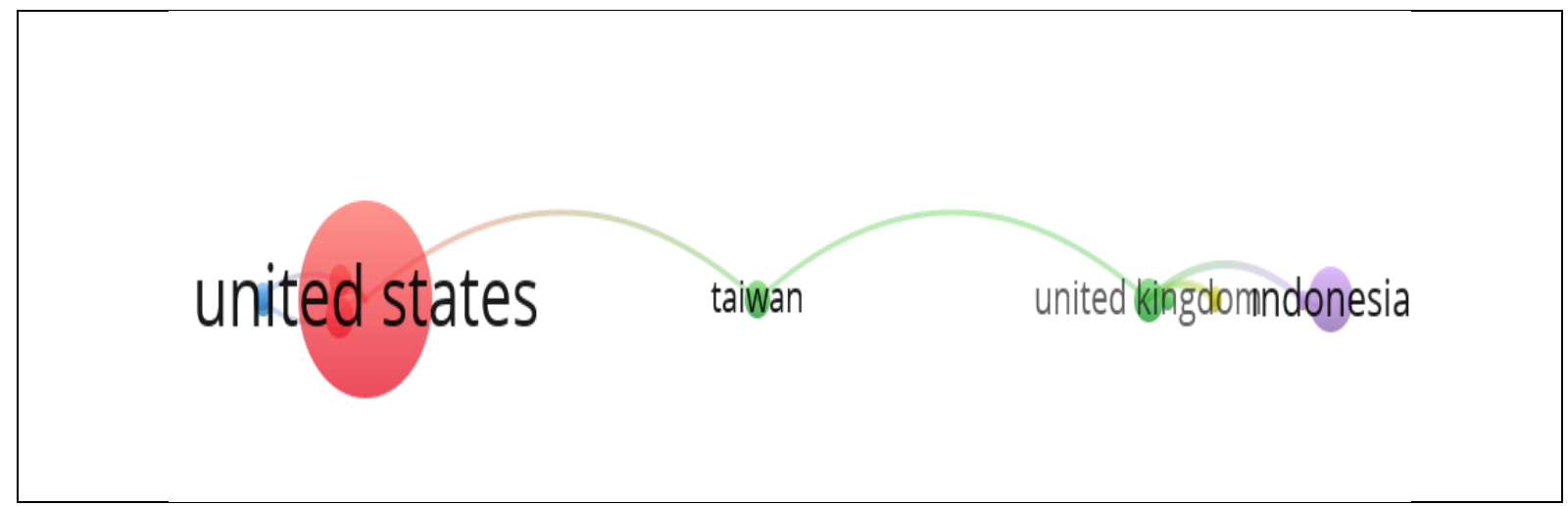

Ülkelerin birbirlerinin yayınlarına yaptıkları atıf haritası Şekil 11'de yer almaktadır. A $\breve{g}$ haritasından da izlenebildiği gibi, diğer ülkelere en fazla kaynaklık eden ülke ABD'nin yayınlarıdır. Daha sonra Endonezya'nın ve Birleşik Krallığın yayınlarının etkileri açıkça dikkat çekmektedir.

Şekil 12: 2000-2020 Yılları arasında Scopus Veri Tabanında Yayınlanan Yayınların Ülkeler Arasındaki Yoğunluk Haritası

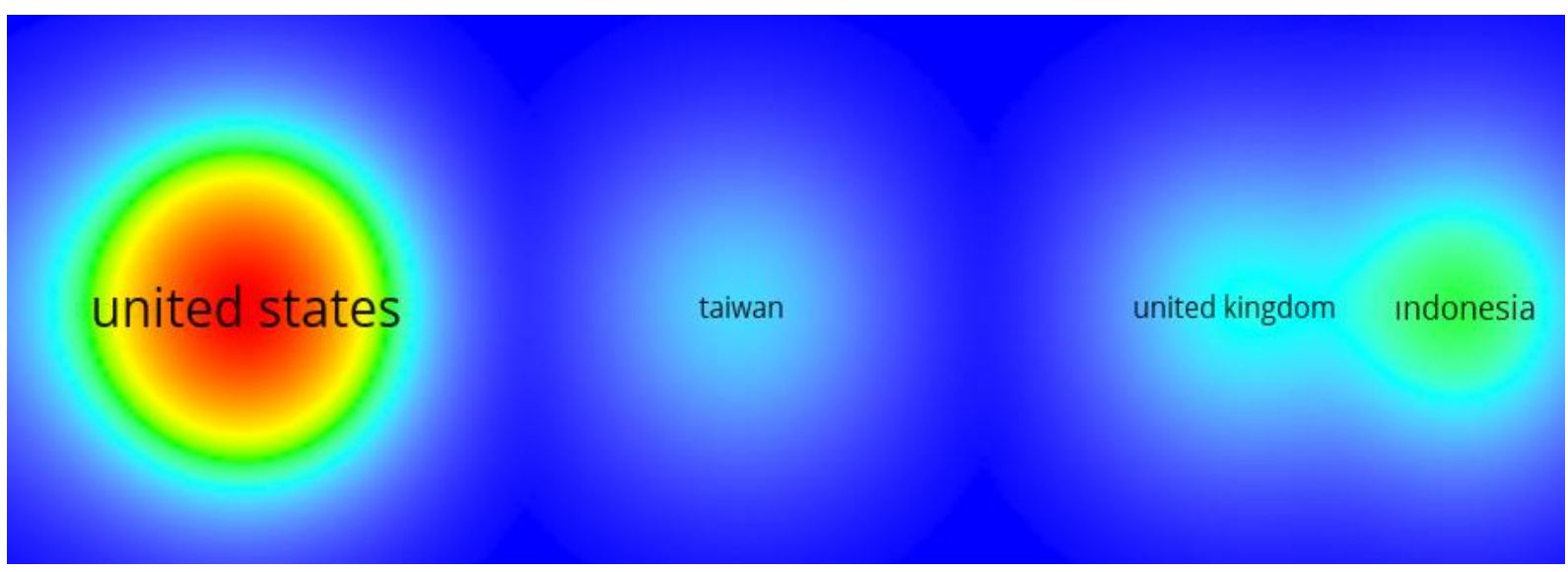


Ülkelerin bibliyografik eşleştirme verilerine göre aldıkları atıfların yoğunluk haritası Şekil 12 görseli üzerinde görülmektedir. Muhasebenin teknoloji ile bütünleşmesini konu alan çalışmalara yapılan atıfların yoğunlaştığı kümeleri; ABD, Endonezya, Birleşik Krallık ve Tayvan oluşturmaktadır.

\subsubsection{Alıntı yapılan yazarların (cited authours) haritalanması}

VOSviewer programında atıf alan yazarlar ve aldıkları atıflara göre görsel yoğunluk haritası Şekil 13'de verilmiştir. Yoğunluk haritası oluşturulurken her bir yazar için atıf sayısı eşik değeri "50" olarak seçilmiştir. Daire büyüklüklerinin yazarlara ait yayın sayısını gösterdiği dikkate alındığında en fazla atıf alan yazarlar sadece tek bir çalışmalarına 482 atıf alan Boudreau M. C. ve Robey D.'dir. İki yayınına toplamda 79 atıf alan yazar Sutton S. G.'dir. Diğer yazarlar ise, bir çalışmalarına 52 atıf almışlardır. Yoğunluk haritasına dayanarak Şekil 14 düzenlenmiştir.

Şekil 13: Alınt1 Yapılan Yazarların Haritalaması

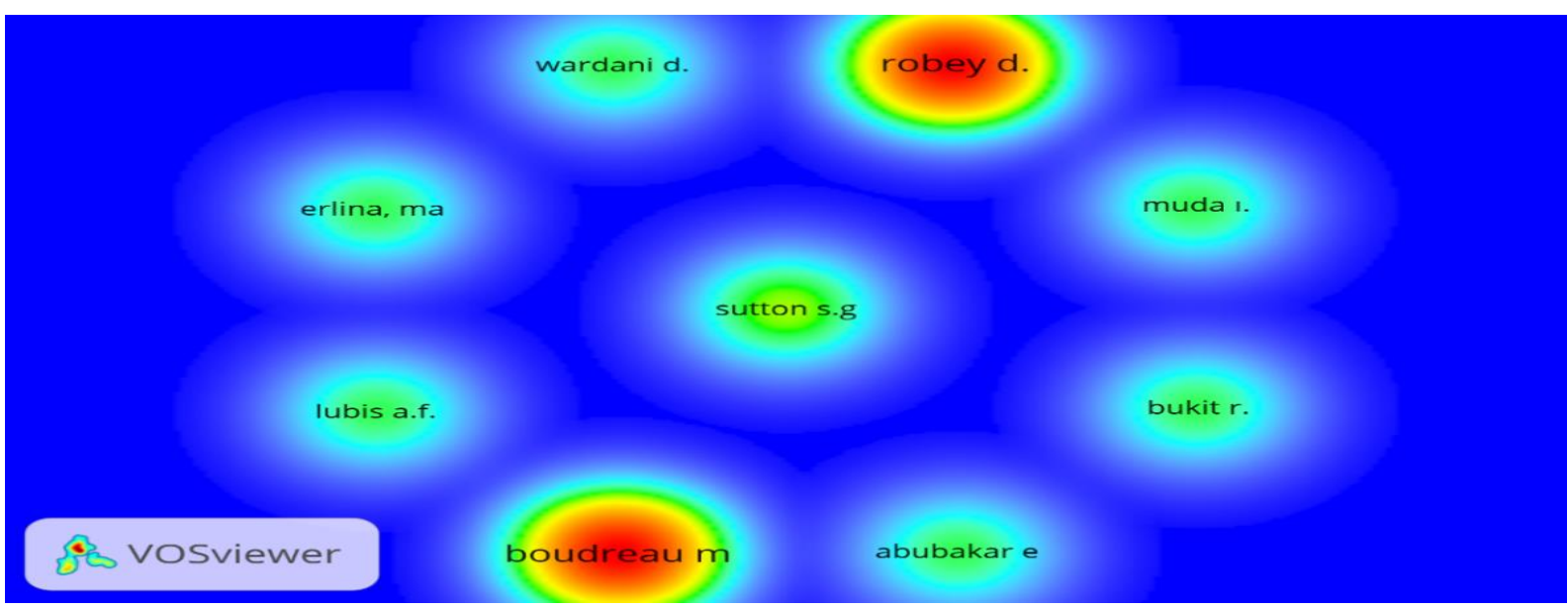

Şekil 14: Literatüre En Fazla Katkı Sağlayan Yazarlar ve Aldıkları Atıflar

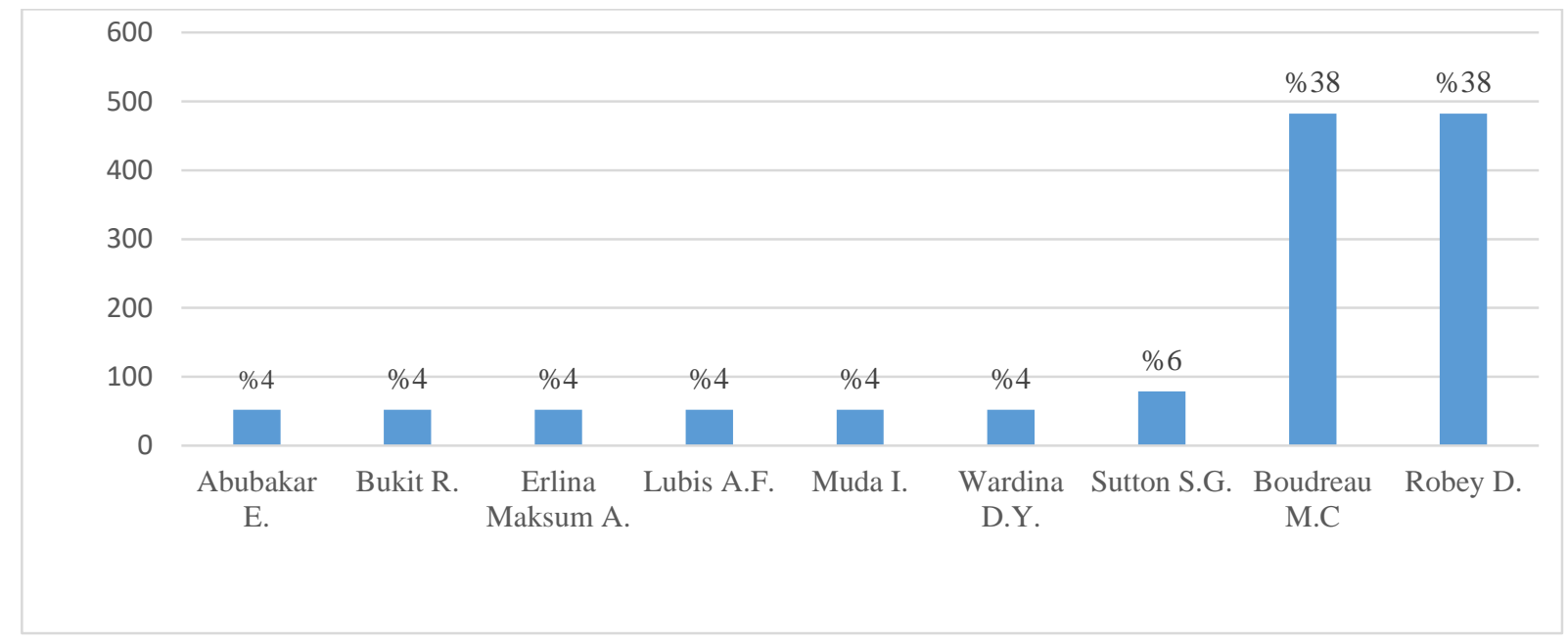

\subsubsection{Scopus veri tabanında yayınlanan yayınlarda atıf alan üniversiteler ve bağlı oldukları ülkeler}

Scopus veri tabanında yapılan araştırmada, 32 ülkenin çalışma konusunda ulaşılan 154 yayınına toplam 1.256 atıf yapılmıştır (Tablo 6). Bu atıfların \%38'i (482 atıf) ABD' de yayınlanan “Georgia State Üniversitesi”nin çalışmalara aittir. Endonezya'da Sumatera Utarak Üniversitesi atıfların \%4'ünü (52 atıf) almıştır. 
Tablo 6: 2000-2020 Yılları arasında Yayınlanan Yayınlarda Atıf Alan Üniversiteler ve Bağlı Oldukları Ülkeler

\begin{tabular}{|c|c|c|c|c|c|}
\hline $\begin{array}{l}\text { Yayın Yapan Üniversiteler ve Aldıkları } \\
\text { Atıflar }\end{array}$ & Atıf & $\begin{array}{c}\text { Yüzde } \\
(\%)\end{array}$ & $\begin{array}{l}\text { Yayın Yapan Üniversiteler ve Aldıkları } \\
\text { Atıflar }\end{array}$ & Atıf & $\begin{array}{c}\text { Yüzde } \\
(\%)\end{array}$ \\
\hline Georgia State Üniversitesi-ABD & 482 & 38 & Central florida Üniversitesi-ABD & 30 & 2 \\
\hline Sumatera Utarak Üniv-Endonezya & 52 & 4 & Boston Üniversitesi-ABD & 26 & 2 \\
\hline Texas Tech Üniversitesi-ABD & 49 & 4 & Hofstra Üniversitesi-ABD & 26 & 2 \\
\hline Aalto Üniversitesi -Finlandiya & 37 & 3 & New York Üniversitesi-ABD & 26 & 2 \\
\hline Turku Üniversitesi-Finlandiya & 37 & 3 & Northeastern Üniversitesi-ABD & 26 & 2 \\
\hline California State Üniversitesi-ABD & 35 & 3 & Suffolk Üniversitesi-ABD & 26 & 2 \\
\hline Chinese Üniversitesi-Hong Kong & 35 & 3 & The State Islamic Institute-Endonezya & 25 & 2 \\
\hline San Jose State Üniversitesi-ABD & 35 & 3 & Diğer üniversiteler & 309 & 25 \\
\hline Toplam & & & & 1.256 & 100 \\
\hline
\end{tabular}

3.3. Muhasebe Mesleğinin Geleceğine Yönelik TR Dizin ve Google School Veri Tabanında Yayınlanan Çalışmalar

Çalışmanın bu bölümünde, dijitalleşen muhasebe biliminin Türkiye'deki gelişim seyrinin izini sürmek amaciyla, 2000-2020 yılları arasında yapılan ve TR dizin ve Google School veri tabanında taranan yayınlar araștırma kapsamına alınmıștır. Mükerrerliği önlemek amacıyla yayınlar tek, tek incelenmiş ve teknolojik gelişmeler boyutunda muhasebe mesleği, eğitimi, denetim mesleği karşılığını tam olarak veren yayınlar çalışma kapsamına alınmıştır.

\subsubsection{TR Dizin ve Google School veri tabanında yayınlanan yayınların yıllara göre yüzde dağılımı}

Türkiye'de muhasebe mesleğinin geleceğine teknolojik gelişmelerin etkisi penceresinden bakıldığında, muhasebe literatürüne 50 dergide 132 yayın ve 8 Kongre olmak üzere toplam 140 bilimsel yayın katkı sağlamıştır. Konu kapsamında 2002 ve 2004 yıllarında \%0,7 yayına (1 yayın) 2000, 2001, 2003 ve 2010 yıllarında ise bir yayına ulaşılmamıştır. Şekil 15`de izlenebildiği gibi 2012 yılından itibaren artış gösteren yayın yüzdesi 2018 yılında \%17 'dir (24 yayın). 2019 yılında \% 20 (28 yayın) 2020 yılında ise, \%16'dır (23 yayın).

Şekil 15: 2000-2020 Yılları arasında TR Dizin ve Google School Veri Tabanında Yayınlanan Yayınların Yüzde Dağılımı ve Büyüme Eğilimi

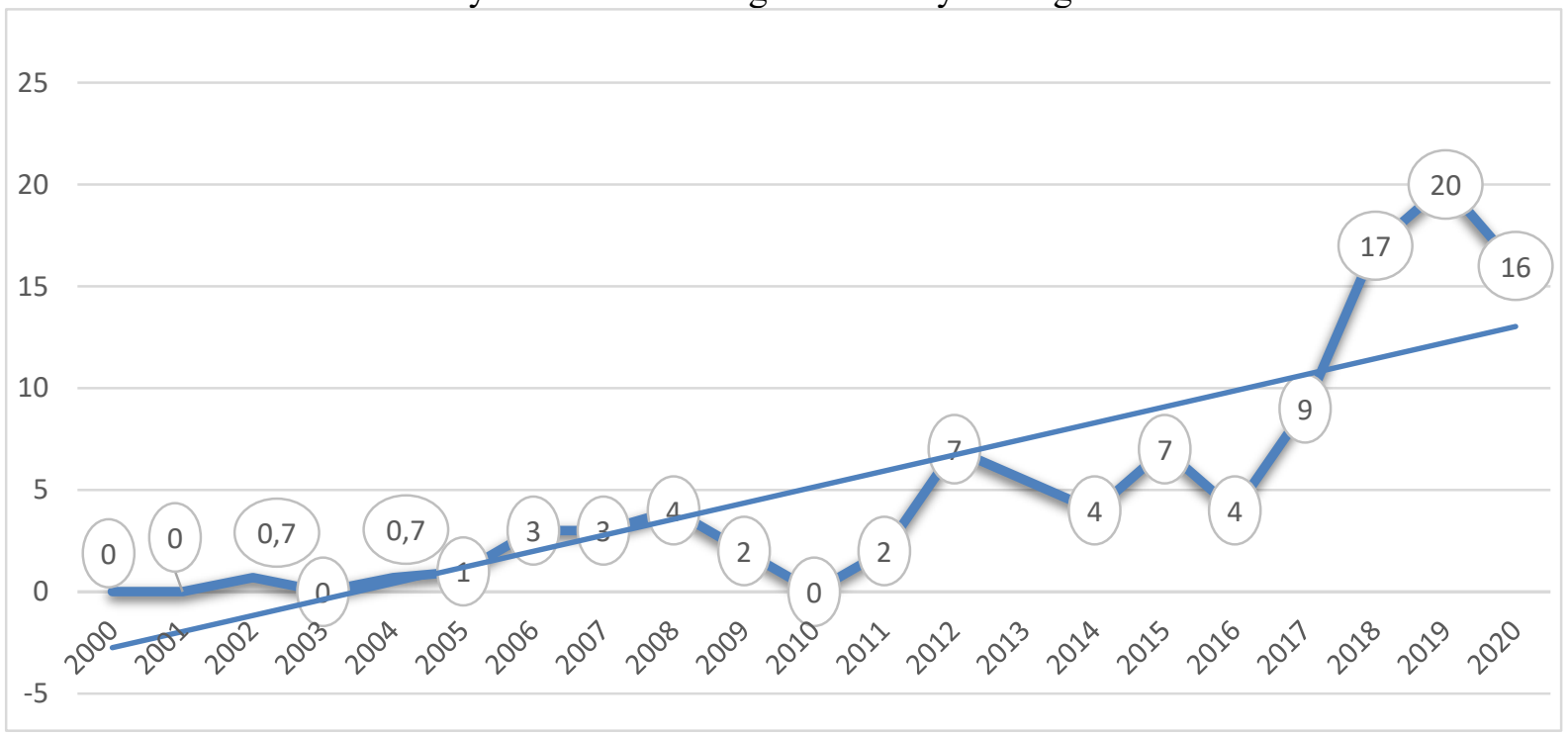

\subsubsection{TR Dizin ve Google School veri tabanında yayınlanan yayınların dergilere göre dağılımı}

Muhasebe mesleğinin teknolojik gelişimine en fazla katkı sağlayan dergilerin başında \%14 ile (20 yayın) "Muhasebe ve Finansman" dergisi gelmektedir. "Muhasebe Bilim Dünyası" dergisi \%9 (12 yayın), "Muhasebe ve Vergi Uygulamalarl" dergisi ise \%7 ile (10 yayın) en fazla katkı sağlayan dergilerdir. 28 dergi tek bir yayın ile konu kapsamında katkı sağlamıştır (Tablo 7). 
Tablo 7: 2000-2020 Yılları arasında Yayınlanan Yayınların Dergilere Göre Dağılımı

\begin{tabular}{|c|c|c|c|c|c|}
\hline Yayın Yapan Dergiler & $\begin{array}{l}\text { Yayın } \\
\text { Sayısı }\end{array}$ & $\begin{array}{c}\text { Yüzde } \\
(\%)\end{array}$ & Yayın Yapan Dergiler & $\begin{array}{l}\text { Yayın } \\
\text { Sayısı }\end{array}$ & $\begin{array}{c}\text { Yüzde } \\
(\%)\end{array}$ \\
\hline Muhasebe ve Finansman Dergisi & 20 & 14 & Enderun Dergisi & 1 & 0,7 \\
\hline Muhasebe Bilim Dünyası Dergisi & 12 & 9 & Erciyes Üniversitesi İIBBF Dergisi & 1 & 0,7 \\
\hline Muhasebe ve Vergi Uygulamaları Dergisi & 10 & 7 & $\begin{array}{l}\text { Frrat Üniversitesi Sosyal Bilimler } \\
\text { Dergisi }\end{array}$ & 1 & 0,7 \\
\hline Muhasebe ve Denetime Bakış & 9 & 6,4 & $\begin{array}{l}\text { İstanbul Ticaret Üniversitesi Sosyal } \\
\text { Bilimler D. }\end{array}$ & 1 & 0,7 \\
\hline Mali Çözüm & 6 & 4,3 & $\begin{array}{l}\text { "İş, Güç" Endüstri İlişkileri ve İnsan } \\
\text { Kaynakları D. }\end{array}$ & 1 & 0,7 \\
\hline Turkish Studies-Social Sciences & 6 & 4,3 & Kara Harp Okulu Bilim Dergisi & 1 & 0,7 \\
\hline $\begin{array}{l}\text { Dumlupınar Üniversitesi Sosyal Bilimler } \\
\text { Dergisi }\end{array}$ & 4 & 3 & $\begin{array}{l}\text { Karadeniz Teknik Üniv. Sos. Bil. Enst. } \\
\text { SBD }\end{array}$ & 1 & 0,7 \\
\hline $\begin{array}{l}\text { Selçuk Üniversitesi İİBF } \\
\text { Sosyal ve Ekonomik Araş. Dergisi }\end{array}$ & 4 & 3 & Manas Sosyal Araştırmalar Dergisi & 1 & 0,7 \\
\hline Vergi Sorunları Dergisi & 4 & 3 & Marmara Üniversitesi Öneri Dergisi & 1 & 0,7 \\
\hline $\begin{array}{l}\text { Atatürk Üniversitesi İktisadi ve İdari } \\
\text { Bilimler Dergisi }\end{array}$ & 3 & 2,1 & Niğde Üniversitesi İİBF D. & 1 & 0,7 \\
\hline $\begin{array}{l}\text { Avrasya Sosyal ve Ekonomi Araştırmaları } \\
\text { Dergisi }\end{array}$ & 3 & 2,1 & $\begin{array}{l}\text { Organizasyon ve Yönetim Bilimleri } \\
\text { Dergisi }\end{array}$ & 1 & 0,7 \\
\hline Avrasya Uluslararası Araştırmalar dergisi & 3 & 2,1 & Ömer Halisdemir Ünv. İIBF D. & 1 & 0,7 \\
\hline $\begin{array}{l}\text { Ahi Evran Üniversitesi Kırşehir Eğitim } \\
\text { Fakültesi Dergisi }\end{array}$ & 2 & 1,4 & $\begin{array}{l}\text { Selçuk Üniversitesi Sosyal Bilimler } \\
\text { Enstitüsü Dergisi }\end{array}$ & 1 & 0,7 \\
\hline Akademik Sosyal Araştırmalar Dergisi & 2 & 1,4 & Selçuk Üniversitesi Karaman İİBF D. & 1 & 0,7 \\
\hline Akdeniz İ̈BF Dergisi & 2 & 1,4 & $\begin{array}{l}\text { Selçuk Üniversitesi Sosyal Bilimler } \\
\text { MYO D. }\end{array}$ & 1 & 0,7 \\
\hline $\begin{array}{l}\text { Anemon Muş Alparslan Üniversitesi } \\
\text { Sosyal Bilimler D. }\end{array}$ & 2 & 1,4 & TISK Akademi & 1 & 0,7 \\
\hline $\begin{array}{l}\text { Avrasya Sosyal ve Ekonomi Araştırmaları } \\
\text { Dergisi }\end{array}$ & 2 & 1,4 & $\begin{array}{l}\text { Uluslararası İktisadi ve İdari İncelemeler } \\
\text { Dergisi }\end{array}$ & 1 & 0,7 \\
\hline $\begin{array}{l}\text { Bilecik Şeyh Edebali Üniversitesi Sosyal } \\
\text { Bilimler Dergisi }\end{array}$ & 2 & 1,4 & Uluslararası Sosyal Araştırmalar Dergisi & 1 & 0,7 \\
\hline $\begin{array}{l}\text { Çukurova Üniversitesi Sosyal Bilimler } \\
\text { Enstitüsü Dergisi }\end{array}$ & 2 & 1,4 & $\begin{array}{l}\text { Uluslararası Toplum Araştırmaları } \\
\text { Dergisi-I }\end{array}$ & 1 & 0,7 \\
\hline Sayıştay Dergisi & 2 & 1,4 & $\begin{array}{l}\text { Uluslararası Yönetim İktisat ve İşletme } \\
\text { Dergisi }\end{array}$ & 1 & 0,7 \\
\hline $\begin{array}{l}\text { Süleyman Demirel Üniversitesi İ̈BF } \\
\text { Dergisi }\end{array}$ & 2 & 1,4 & Üçüncü Sektör Sosyal Ekonomi Dergisi & 1 & 0,7 \\
\hline Vergi Raporu & 2 & 1,4 & Vergi Dünyası Dergisi & 1 & 0,7 \\
\hline Bilgi Ekonomisi ve Yönetimi Dergisi & 1 & 0,7 & $\begin{array}{l}\text { Yönetim ve Ekonomi Araştırmaları } \\
\text { Dergisi }\end{array}$ & 1 & 0,7 \\
\hline $\begin{array}{l}\text { Çankırı Karatekin Üniversitesi Sosyal } \\
\text { Bilimler Enstitüsü Dergisi }\end{array}$ & 1 & 0,7 & $\begin{array}{l}\text { Yönetim ve Ekonomi: Celal Bayar Ünv. } \\
\text { İIBF D. }\end{array}$ & 1 & 0,7 \\
\hline $\begin{array}{l}\text { ÇOMÜ Dergileri Girişimcilik ve Kalkınma } \\
\text { Dergisi }\end{array}$ & 1 & 0,7 & Kongreler & 8 & 6 \\
\hline Elektronik Sosyal Bilimler Dergisi & 1 & 0,7 & & & \\
\hline Toplam & & & & 140 & 100 \\
\hline
\end{tabular}

\subsubsection{Bağlı olduğu üniversitelere göre yazarların dağılımı}

Çalışma konusuna 255 akademisyen ve SMMM, YMM ve uzman olmak üzere 15 serbest çalışan ile toplamda 270 meslek mensubu katkı sağlamıştır. Tablo 8'de 270 yazarın bağlı olduğu 84 üniversite yer almaktadır.

Tablo 8: Yazarların Bağlı Olduğu Üniversiteler

\begin{tabular}{lc}
\hline Yazarların Bağlı Oldukları Üniversiteler & Yazar SayıSı \\
\hline Dokuz Eylül Üniversitesi & 18 \\
\hline Süleyman Demirel Ünv.-Selçuk Ünv. & 10 \\
\hline Anadolu Üniversitesi-Bilecik Şeyh Edebali Üniversitesi & 9 \\
\hline İstanbul Aydın Üniversitesi & 7 \\
\hline Bandırma Onyedi Eylül Ünv.-İstanbul Ticaret Ünv.-Marmara Ünv. & 6 \\
\hline İnönü Ünv -Kafkas Üniv.-Necmettin Erbakan Ünv.-Yeditepe Ünv.-Ondokuz Mayıs Ünv. & 5 \\
\hline
\end{tabular}


Tablo 8 (Devamı): Yazarların Bağlı Olduğu Üniversiteler

\begin{tabular}{lc}
\hline Yazarların Bağlı Oldukları Üniversiteler & Yazar Sayısı \\
\hline Celal Bayar Ünv.-Çanakkale Onsekiz Mart Ünv.-Düzce Ünv.-Eskişehir Osmangazi Ünv. & 4 \\
Erzincan Binali Y1ldırım Ünv.-Fatih Ünv.-Kayseri Ünv.-Kahramanmaraş Sütçü İmam Ünv. & \\
Pamukkale Ünv.-Sakarya Ünv.-Tokat Gaziosmanpaşa Ünv. & 3 \\
\hline Abant İzzet Baysal Ünv.-Afyon Kocatepe Ünv.-Ahi Evran Ünv.-Ankara Ünv. & \\
Bursa Uludağ Ünv.-Fıtrat Ünv.-İzmir Katip Çelebi Ünv.-Karamanoğlu Mehmetbey Ünv. \\
Muğla Sitk1 Koçman Ünv.- Milli Savunma Ünv. - Osmaniye Korkut Ata Ünv.-Trakya Ünv. \\
\hline Akdeniz Ünv.- Alanya Alaaddin Keykubat Üniv.-Bartın Ünv.-Başkent Ünv. \\
Burdur Mehmet Akif Ersoy Üniv.-Bitlis Eren Ünv.-Çukurova Ünv.-Giresun Ünv. \\
Gaziosmanpaşa Ünv.- Gümüşhane Ünv.-İstanbul Bilgi Ünv.-İstanbul Medeniyet Ünv. \\
İstanbul Ünv.-̇̇zmir Demokrasi Ünv.-Kocaeli Ünv.-Karadeniz Teknik Ünv. \\
Karabük Ünv.-Mustafa Kemal Ünv.-Munzur Ünv.-Ordu Ünv.-Yozgat Bozok Ünv.-Yalova Ünv. \\
\hline Ağrı İbrahim Çeçen Ünv.- Amasya Ünv.- Bahçeşehir Ünv.- Balıkesir Ünv.-Bayburt Ünv. \\
Dumlupınar Ünv.- Erzurum Teknik Ünv.- Erciyes Ünv.- Eastern Mediterranean Ünv. \\
Gazi Ünv.-Gaziantep Ünv- Hitit Ünv.-Harran Ünv.-Hatay Mustafa Kemal Ünv-İzmir Bakırçay Ünv. \\
Kastamonu Ünv.-Kilis 7 Aralı Ünv.-Kütahya Dumlupınar Ünv.-Kırkkale Ünv. \\
Mehmet Akif Ersoy Ünv.- Niğde Ömer Halisdemir Üniv.- Özyeğin Ünv. \\
Sivas Cumhuriyet Ünv.-Siirt Ünv.- TOBB Ekonomi ve Teknoloji Ünv. \\
\hline Uzman, YMM ve SMM \\
\hline Toplam
\end{tabular}

Şekil 16'da yazarların bağlı oldukları ilk beş üniversite yer almaktadır. Muhasebenin teknolojik gelişim sürecine \%21 (18 yazar) ile en fazla katkı sağlayan üniversite Dokuz Eylül Üniversitesi'dir. Süleyman Demirel üniversitesi ve Selçuk üniversitesi \%11 (10 yazar), Anadolu ve Bilecek Şeyh Edebali üniversitesi \%10 (9 yazar) düzeyinde katkı sağlamıştır.

Şekil 16: Yazarların Bağlı Oldukları İlk Beş Üniversite

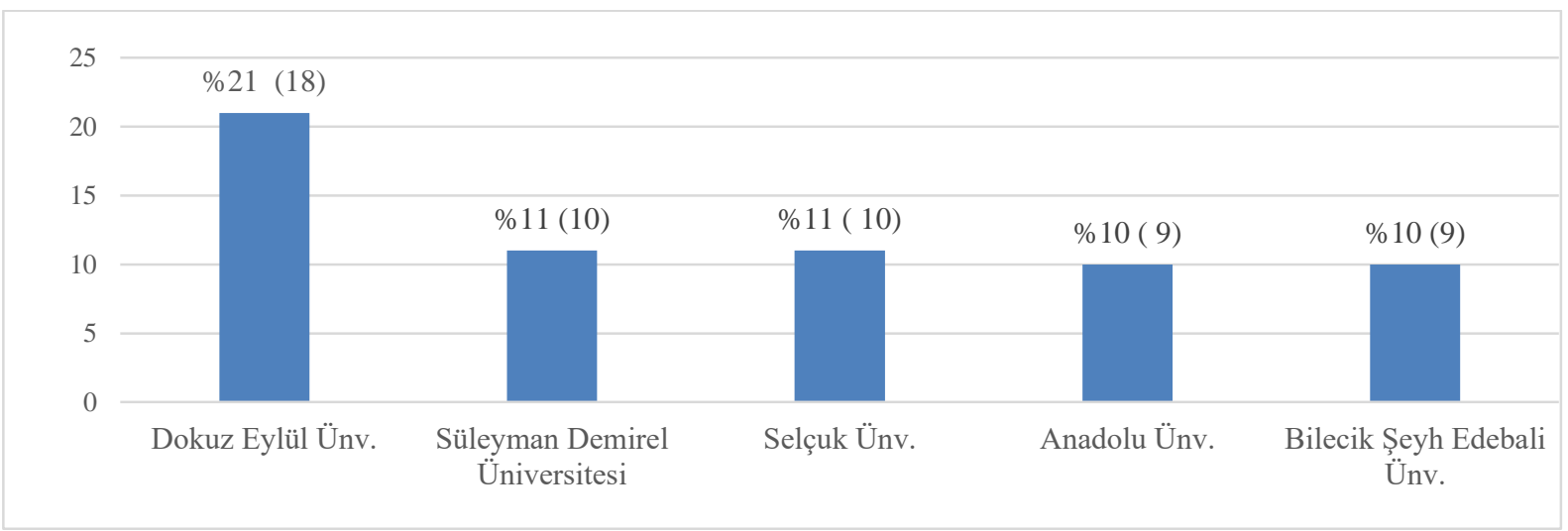

\subsubsection{Yayınların yazar sayısı ve dağılımı}

Yazarların yayın sayısına göre dağılımlarına yer verildiği bu bölümde,140 yayının \%28'i tek yazarlı çalışmadır (Tablo 9). Yayınların \%53'ü iki yazarlı, \%18'i üç yazarlı ve \%0,14'ü dört yazarlı yayınlardır.

Tablo 9: Yayınların Yazar Sayısı ve Yüzde Dağılımı

\begin{tabular}{lcc}
\hline Yayınlardaki Yazar Sayısı & Yayın Sayısı & Yüzde (\%) \\
\hline 1 & 39 & 28 \\
\hline 2 & 74 & 53 \\
\hline 3 & 25 & 18 \\
\hline 4 & 2 & 0,14 \\
\hline Toplam & $\mathbf{1 4 0}$ & $\mathbf{1 0 0}$ \\
\hline
\end{tabular}

\subsubsection{Yazarların unvanlarına göre dağılımı}

Şekil 17'i incelendiğinde literatüre en fazla katkısı olan yazarlar \%32 ile (87 yayın) doktor öğretim üyeleridir. \%20 ile (54 yayın) doçent unvanına sahip akademisyenler, \%11 (31 yayın) ile de, profesör unvanına sahip akademisyenler sıralamada yerlerini almışlardır. 
Şekil 17: Yazarların Unvanlarına Göre Dağglımı

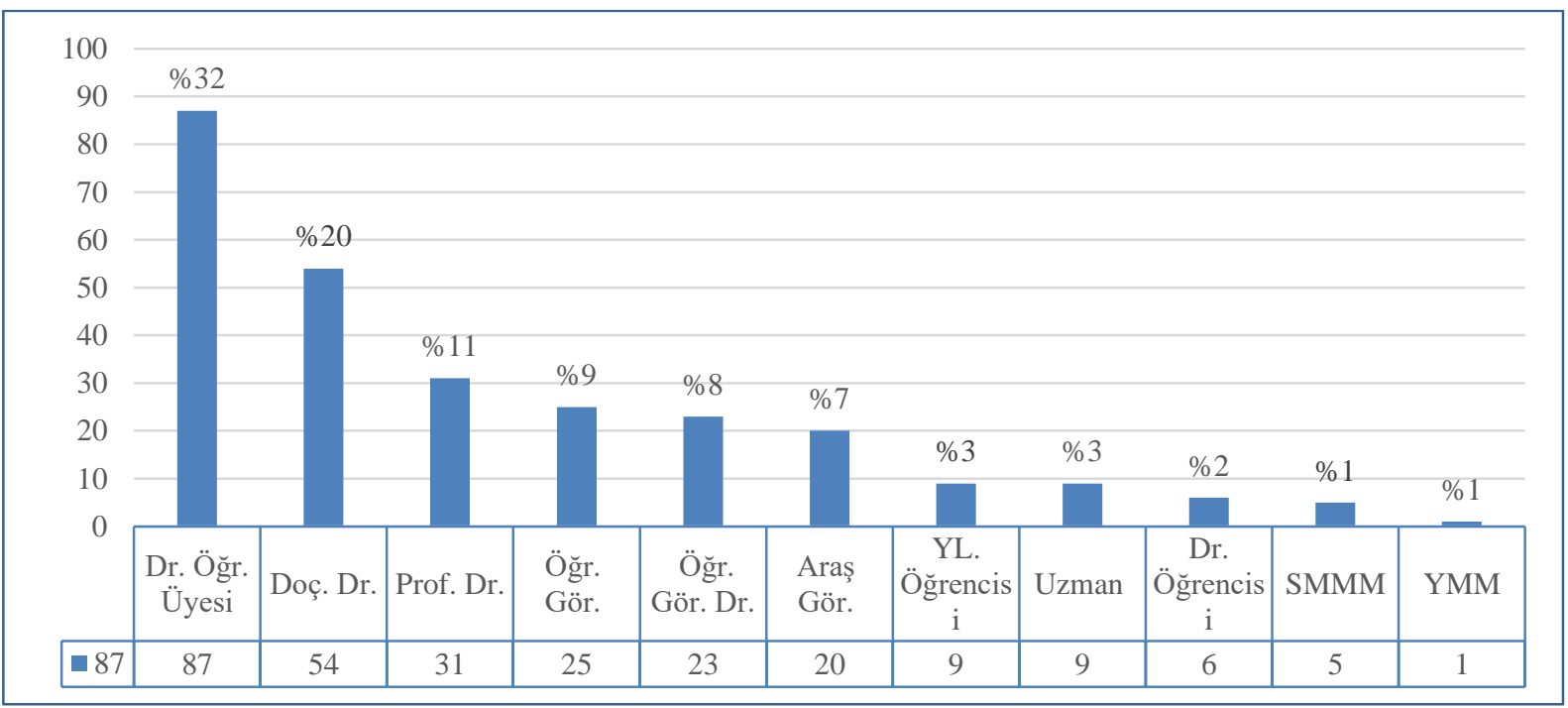

\section{SONUÇ}

Teknolojideki dev adımlarla başlayan değişim rüzgarları muhasebe bilimini yeni donanımlarla yeni bir konuma taşımaya başlamıştır. Genç yüzyılının 20'li yaşları akıllı sistemler sayesinde, tek tuşla veri kalitesinin artırmasından verilerin raporlanmasına ve analizine kadar çok ciddi gelişmelere sahne olmaktadır. Muhasebe meslek mensupları artık farklı boyutlarda düşünme sürecine girmiştir.

Yapılan literatür taramasında, teknolojinin sürekli gelişimiyle muhasebe ve iş ortamının geleceği belirsizliğini koruduğu, manuel olarak yapılan hesapların hazırlanması gibi basit, yüksek düzeyde standartlaştırılmış insan faaliyetlerinin gerektirdiği iş yükünün ortadan kalkacağı ancak yeni iş yüklerinin de beraberinde geleceği, faaliyetlerin ise yönetim için daha şeffaflaşacağı görüssler arasındadır. Muhasebe meslek mensuplarının; bilgiyi elde etmesi ve yönetmesi, teknolojiye hakimiyeti, mega trendlerdeki gelişmeleri takip etmesi, geleceğin büyüsünün heyecanı içinde değişim potansiyeline entegre olması beklenmektedir.

Çalışmada 2000-2020 yılları arasında Web of Science' da yer alan ve "Social Science Citation Index" ve "Emerging Sources"'da endekslenen dergilerde, Scopus'da, ve yerli yayınların izini sürmek içinde TR dizin ve Google School'da yayınlanan makaleler kapsamında bibliyometrik analiz yapılmıştır. Elde edilen veriler bibliyometrik analiz yazılımı Vosviewer haritalama tekniğiyle görselleştirilmiştir. Çalışma ile araştırmacılar için sistematik bir bilgi haritası sağlamak amaçlanmıştır.

Web of Science'da 34 ülkenin 87 yayınına ulaşılmıştır. Yayınların ülkelere göre dağılımının bibliyometrik analizinde \%17 ile en fazla yayını olan ülke ABD'dir. Yayınlarına en fazla atıf alan ülke $\% 29$ pay ile yine ABD'dir. En fazla yayını olan üniversiteler ise her ikisinde de 29 yayın ve \%6'l1k pay ile Finlandiya'da Aalto ve Turku Üniversiteleridir. ABD'de Arkansas üniversitesi 26 yayın ile $\% 4,9$ paya sahiptir.

Scopus veri tabanında 32 ülkenin 154 yayınına ulaşılmıştır. ABD 20 yayın ve \%13 ile birinci sıradadır. Yayınlarına en fazla atıf alan ülke 751 atıf ve $\% 60$ pay ile ABD'dir. En fazla yayını olan üniversiteler ise 482 atıf ve \%38 pay ile ABD'de Georgia State Üniversitesidir.

Her iki veri tabanına göre, yayınların ülkelere göre dağılımının bibliyometrik analizinde ilk ona giren ülkeler ABD, İngiltere, Kanada, Endonezya, Avustralya, Çin'dir. En fazla atıf alan ilk on ülke; ABD, Finlandiya, İngiltere, Kanada, Tayvan, Avustralya'dır. Yayınlanan çalışmalarda en fazla atıf alan üniversiteler ise Finlandiya'da Turku Üniversitesi ve Aalto Üniversitesi'dir. Veri tabanlarında yayınlanan yayınlar arasında Türkiye kaynaklı bir yayına rastlanılmamıştır.

Türkiye'de Muhasebe mesleğinin dijital geleceğini konu alan çalışmalara ulaşabilmek için TR dizin ve Google School veri tabanı taranmıştır. Konu kapsamında yapılan çalışmada toplam 50 dergide 132 makale ile 8 kongrenin katkı sağladığı tespit edilmiştir. En fazla çalışma 2019 yılında \% 20 pay ile 28 yayındır. 2020 yılında ise, yayın sayısı $\% 16$ pay ile 23 yayındır. 
Çalışmada, ivme kazanan teknolojik gelişmelerin muhasebe bilimine ve uygulamalarına getirdiği gelişmeleri konu edinen çalışmaların bibliyometrik analizin yapılmasıyla akademisyenlere geleceğe yönelik eğilimler hakkında öngörüde bulunabilmeleri için sistematik bir harita sunulmuştur.

Etik Beyan: Bu çalışmada "Etik Kurul” izini alınmasını gerektiren bir yöntem kullanılmamıştır.

Ethics Statement: In this study, no method requiring the permission of the "Ethics Committee" was used.

\section{KAYNAKÇA}

Burritt, R., \& Christ, K. (2016). Industry 4.0 and environmental accounting: A new revolution?. Asian Journal of Sustainability and Social Responsibility, 1, 23-38. https://doi.org/10.1186/s41180$\underline{016-0007-\mathrm{y}}$

Cobo, M. J., López-Herrera, A. G., \& Herrera-Viedma, E. (2015). A relational database model for science mapping analysis. Acta Polytechnica Hungarica, 12(6), 43-62. http://acta.uniobuda.hu/Cobo_Lopez-Herrera_Herrara-Viedma_62.pdf

Eck, N. J. V., \& Waltman, L. (2020). VOSviewer manual. https://www.vosviewer.com

Ford, M. (2009). The lights in the tunnel: Automation, accelerating technology and the economy of the future. Acculant Publishing.

Frey, Y. C. B., \& Osborne, M. A. (2013). The future of employment: How susceptible are jobs to computerisation?. Oxford Martin Programme on Technology and Employment Working Paper, September (17), 1-77. https://www.oxfordmartin.ox.ac.uk/downloads/academic/future-ofemployment.pdf

Ghani, E. K., \& Muhammad, K. (2019). Industry 4.0: Employers' expectations of accounting graduates and its implications on teaching and learning practices. International Journal of Education and Practice, 7(1), 19-29. https://files.eric.ed.gov/fulltext/EJ1209944.pdf

Güvemli, O. (2012). Tarih eğitimi ve muhasebe tarihi eğitimi. Muhasebe ve Finans Tarihi Araştırmaları Dergisi, (2), 5-21. https://dergipark.org.tr/tr/download/article-file/319977

Khalil, G. M., \& Crawford, C. A. G. (2015). A bibliometric analysis of US-based research on the behavioral risk factor surveillance system. American Journal of Preventive Medicine, 48(1), 5057. https://doi.org/10.1016/j.amepre.2014.08.021. Epub 2014 Nov 6

Kıdak, L. B., Demir, H., \& Özdemir, E. (2017). Bilimsel haritalama yöntemiyle hastane yönetimi alanındaki tematik değişimin analizi. Genel Tip Dergisi, 27(2), 43-50. https://doi.org/10.15321/GenelTipDer.2017.141

Kruskopf, S., Lobbas, C., Meinander, H., \& Söderling, K. (2019). M. Martikainen, \& O. M. Lehner (Eds.), Digital accounting: Opportunities, threats and the human factor. ACRN Oxford Journal of Finance and Risk Perspectives, 8/Special Issue Digital Accounting, 1-15. http://www.acrnjournals.eu/iframe-8/jofrp/jofrpvol8_specialissue.html

Kurutkan, M. N. \& Orhan, F. (2018). Kalite prensiplerinin görsel haritalama tekniğine göre bibliyometrik analizi. Sage Yayınc1lık.

Martinez, M. A., Cobo, M. J., Herrera, M., \& Herrera-Viedma, E. (2015). Analyzing the scientific evolution of social work using science mapping. Research on Social Work Practice, 25(2), 257277. https://sci2s.ugr.es/sites/default/files/ficherosPublicaciones/1730_MartinezMAResearch\%20on\%20Social\%20Work\%20Practice-2015.pdf

Milfont, T. L. \& Page, E. (2013). A bibliometric review of the first thirty years of the journal of $\begin{array}{llll}\text { environmental psychology. } & \text { Psyecology, 4(2), }\end{array}$ https://doi.org/10.1080/21711976.2013.10773866

Nixon, R. (2012). The future of the accounting profession - 12 future predictions. Proactive Accountants Network, http://proactiveaccountants.net 
Perianes-Rodriguez, A., Waltman, L., \& Van Eck, N. J. (2016). Constructing bibliometric networks: A comparison between full and fractional counting. Journal of Informetrics, 10(4), 1178-1195. https://doi.org/10.1016/j.joi.2016.10.006

Pradhan, P. (2016). Science mapping and visualization tools used in bibliometric \& scientometric studies: An overview. Inflibnet Newsl. Artic, 23(4), 19-33. https://ir.inflibnet.ac.in/bitstream/1944/2132/1/INFLIBNET\%20NEWSLETTER\%20Vol.23\%2 0No.\%204\%20(October-\%20December\%202016).pdf

Schwab, K., \& Samans, R. (2016). World economic forum: The future of jobs report. http://reports.weforum.org/future-of-jobs-2016/

Statisca. (2019). https://www.statista.com/markets/418/technology-telecommunications/

World Economic Forum. (2016). https://www.weforum.org/press/2016/01/five-million-jobs-by-2020the-real-challenge-of-the-fourth-industrialrevolution/

World Economic Forum. (2019). https://www.weforum.org/agenda/2019/04/how-much-data-isgenerated-each-day-cf4bddf29f/

Zhang, K., Wang, Q., Liang, Q., \& Chen, H. (2016). A Bibliometric analysis of research on carbon tax from 1989 to 2014. Renewable and Sustainable Energy Reviews, 58, 297-310. https://doi.org/10.1016/j.rser.2015.12.089

Zupic, I., \& Čater, T. (2015). Bibliometric methods in management and organization. Organizational Research Methods, 18(3), 429-472. https://doi.org/10.1177/1094428114562629 